\title{
Türkçenin yabancı dil olarak öğretiminde yöntem
}

Gökçen GöÇEN1

\begin{abstract}
APA: Göçen, G. (2020). Türkçenin yabancı dil olarak öğretiminde yöntem. RumeliDE Dil ve
\end{abstract} Edebiyat Araştirmaları Dergisi, (18), 23-48. DOI: 10.2900o/rumelide.705499.

\section{$\ddot{O} \mathbf{z}$}

Bir yabancı dilin öğretimi söz konusu olduğunda dilin nasıl öğretileceği de söz konusu olmaktadır. Bu süreçte dil öğretim yöntemlerinden yararlanılmaktadır. Türkçenin yabancı dil olarak öğretiminde de dil öğretim yöntemlerini bilmek Türkçe öğretim sürecine olumlu etki yapacaktır. Bu süreçte, yöntemlerin hangi dil öğretim yaklaşımlarıyla ilgili olduğunu fark etmek, yöntem hakkında bilgi sahibi olmak yöntemlerin sınıf ortamına aktarılması için önemlidir. Bunlar, dil öğretim süreci içinde ne zaman, hangi yönteme başvurulacağı konusunda da bir dil öğretmenine yol gösteren özellikler arasındadır. Bununla birlikte, sınıf ortamında yapılacak uygulamalar için öğretmenlerin dil öğretim yöntemlerindeki öğretmen ve öğrenci rollerinin neler olduğunu anlaması ve dil öğretim yöntemlerinin olumlu ve olumsuz taraflarının farkında olması bir gerekliliktir. Bu önem ve gerekle, Türkçenin yabancı dil olarak öğretiminin etkililiğini arttırmak adına, dil öğretim yöntemlerindeki öğretmen-öğrenci rollerini ve yöntemlerin olumlu-olumsuz özelliklerini ortaya koymayı amaçlayan bu çalışma, literatür çalışmasına dayalı bir derleme çalışmasıdır. Literatür çalışması doğrultusunda dil öğretiminde kullanılan yöntemlerdeki öğretmen-öğrenci rolleri ve yöntemlerin olumlu-olumsuz özellikleri derlenmiştir. Bu çalışmada, yöntemlerdeki öğretmen-öğrenci rollerinin ve yöntemlerin olumlu-olumsuz özelliklerinin açıklamaları ve örnekleri bir bütün hâlinde sunulmuştur. Böylece, bir dil öğretmenine hangi yöntemi, ne zaman, niçin seçmesi gerektiğiyle ilgili bir bakış açısı da sunulmuş olmuştur. Bu çalışmanın, öğretim sürecini etkili bir hâle getirmede, Türkçeyi yabancı dil olarak öğretenlere yardımcı olacağı düşünülmektedir.

Anahtar kelimeler: Dil öğretimi, Türkçe eğitimi, Türkçenin yabancı dil olarak öğretimi, dil öğretim yöntemleri.

\section{Methodology in teaching Turkish as a foreign language}

\begin{abstract}
The practice of teaching a foreign language is concerned with the ways languages are taught. This means language teaching methods are exploited in this process. Having the knowledge of language teaching methods will benefit one's practices of teaching Turkish as a foreign language (TFL). In order to transfer methodological knowledge to classroom environment, it is important to have learnt about methods and to recognize the approaches that the methods are related to. These are among the elements that lead a language teacher in terms of "which method to apply" and "when to apply them". In addition, teachers need to understand the roles of themselves and learners in language teaching methods and be aware of positive and/or negative aspects of them so that in-class applications will be effective. To this end, this study aims to reveal teacher-learner roles in language teaching methods and positive and/or negative aspects of them. This is a compilation study based on literature review.
\end{abstract}

$1 \quad$ Dr. Öğr. Üyesi, Fatih Sultan Mehmet Vakıf Üniversitesi, Eğitim Fakültesi, Türkçe ve Sosyal Bilimler Eğitimi Bölümü (İstanbul, Türkiye), ggocen@fsm.edu.tr, ORCID ID: 0000-0001-7552-8406 [Makale kayt tarihi: 21.11.2019-kabul tarihi: 20.03.2020; DOI: 10.29000/rumelide.705499] 
In accordance with literature review, teacher-learner roles in language teaching methods and positive and/or negative aspects of them were compiled. The study presents teacher-learner roles in language teaching methods and positive and/or negative aspects of them as a whole. Therefore, this study provides language teachers with some ideas on which methods to use as well as when and why to use them. It is intended that this study will be of benefit to teachers of TFL to better improve TFL practices.

Keywords: Language teaching, Teaching Turkish, Teaching Turkish as a foreign language, Language teaching methods.

\section{Giriş}

Bir konunun, davranışın öğretimi söz konusu olduğunda öğretilecek olanın nasıl öğretileceği de söz konusu olmaktadır. Eğitimde "Nasıl öğreteceğim?" sorusunun cevabını yaklaşımlar, yöntemler ve teknikler vermektedir. Bir başka deyişle, eğitimde belirlenen her amacın hedef kitleye aktarımında yaklaşım, yöntem ve tekniklerden yararlanılmaktadır (Güzel ve Barın, 2013: 157). Bir yabancı dilin öğretimi söz konusu olduğunda da dil öğretim yaklaşımlarına, yöntemlerine ve tekniklerine başvurulmaktadır. Celce-Mursia'ya (2001: 9) göre yaklaşım genel bir kavramı, yöntem bu yaklaşıma uygun ilkeler kümesini ve teknik ise bir yöntemde kullanılan öğrenme aktivitesini anlatmaktadır.

Geçmişten günümüze yabancı dil öğretiminde, dilin yapısına ya da pratik kullanımına odaklanan birbirinden farklı yaklaşımlar kullanılmıştır (Güçlü, Arslan ve Üstünyer, 2017; Güneş, 2013a). Dil öğretim yaklaşımları başlangıçta geleneksel yaklaşımlar olarak dilin yapısına odaklanmışlar ve öğretimde dil bilgisi kurallarını, çeviri yapmayı, ezberlemeyi ön plana çıkarmışlardır. Günümüze gelindiğinde ise dil öğretim yaklaşımlarında iletişim, etkileşim, görev gibi terimler ön plana çımış ve öğretim sürecinde dilin pratik kullanımına odaklanılmıştır. Böylece dil öğretimiyle öğrenenlerin dil becerilerini etkili bir şekilde kullanarak gerçek iletişim ortamlarına katılabilmeleri amaçlanmaya başlanmıştır. Dil öğretim yaklaşımlarının değişmesi ve yenilenmesi dil öğretim yöntemlerinin de değişmesine ya da farklı yöntemlerin ortaya çlkmasına sebep olmuştur. Dil öğretim yaklaşımlarıyla ilişkili olarak dil öğretim yöntemleri de dil öğretiminde, öğrenenlerin farklı becerilerinin geliştirilmesini öncelemişlerdir. Kullanılan tüm yaklaşım ve yöntemlerin ortak noktası ise Aykaç’ın (2015: 172) belirttiği gibi dili en kolay ve en iyi şekilde öğretmek olmuştur.

Yöntem dersin amacına, hedef kitlesine ve öğrenme şartlarına bağlı olarak derste uygulanan yol, dersin sürecini yönlendiren uygulama biçimi olarak tanımlanabilir (Uzuntaş ve Yıldız, 2017: 210). Seyahat, eğitim, meslek yaşamı gibi farklı faktörlerin etkisiyle farklı dillerdeki insanlarla iletişim kurma ihtiyacının artması, dil öğretim yöntemlerinde en uygun olanı aramayı zorunlu hâle getirmiştir. Bugün, yöntemlerin kendi özelliklerinden, öğrenenlerin demografik farklılıklarından ya da farklı becerilerin geliştirilmesi için farklı yöntemlerin kullanılması gerekliliğinden kaynaklanan sebeplerle (Bekleyen, 2015; Calp, 2017; Gür, 1995) "bir tek yabancı dil yönteminden değil, yabancı dil öğretim yöntemlerinden” söz edilmektedir (Kocaman, 1983: 7).

Öğrencilerin dil öğrenim ihtiyaçlarının saptanması, dil öğretim amacının belirlenmesi gibi faktörler dil öğretiminde kullanılacak yöntemlerin seçilmesinde önemlidir (Sebüktekin, 1973; Göçer, 2017a;). Çangal'a göre (2012: 11) belirlenen bu ihtiyaç ve amaca hizmet edecek tüm dil öğretim yöntemleri dil öğretim sürecine dâhil edilebilir. Bu süreçte, yöntemlerin olumlu-olumsuz özellikleri tartışılabilir ve dil öğretiminde dil becerilerini en iyi şekilde geliştirecek olan yöntemlerin çoğundan yararlanılabilir (Kurt, 
2010: 121). Dil öğretim yöntemlerinin seçiminde önerilen çözüm ise "En içteki halkadan başlayarak dışa doğru amaçlara uygun seçimler yaparak seçmeli (eclectic) bir yöntem geliştirmektir.” (Enginarlar, 1983: 67).

Bu bağlamda, bir dil öğretmeni olarak dil öğretim yöntemlerinden bir ya da birkaçının özelliklerini bilmenin etkili bir eğitim-öğretim süreci için yeterli olmadığ fark edilmektedir. Dil öğretim yöntemlerinin çoğunu bilmenin yanı sıra, yöntemleri iyi tanımak ve özelliklerini tam olarak bilmek de yöntemleri uygulama sürecine katabilmek açısından bir gerekliliktir. Dil öğretiminin etkililiğini sağlayabilmenin koşulları arasında dil öğretim yöntemlerini bilmek; bir yöntemin kullanımında öğretmenlerin ve öğrencilerin rollerinin neler olduğunu anlamak; bir yöntemin olumlu ve olumsuz özelliklerinin farkında olmak yer almaktadır. Tüm bunlar, dil öğretim süreci içinde ne zaman, hangi yönteme başvurulacağı konusunda bir dil öğretmenine yol gösteren özellikler arasındadır. Türkçenin yabancı dil olarak öğretiminde de Türkçe öğretmenlerinin dil öğretim yöntemlerini tanımasına, yöntem kullanımı sürecinde öğretmen-öğrenci rollerini anlamasına ve yöntemin olumlu-olumsuz özelliklerinin farkında olmasına ihtiyaç vardır. Böylece öğretmenler öğrenen ihtiyaçlarına, geliştirilmek istenen dil becerisine ve öğretimin hedeflerine yönelik olarak gerekli olan yöntemlerin seçimlerini gerçekleştirebileceklerdir.

Türkçenin yabancı dil olarak öğretimi alanında, öğreticilere dil öğretim yöntemlerini tanıtmayı amaçlayan akademik çalışmaların var olduğu görülmektedir. Bu çalışmalardan bazıları şunlardır: Alver, 2019; Bölükbaş, 2013a; Bölükbaş, 2013b; Bölükbaş, 2013c; Büyükikiz, 2013a; Büyükikiz, 2013b; Calp, 2017; Demir ve Açık, 2011; Derman ve Köksal, 2013; Dilidüzgün, 2015; Durmuş, 2013a; Durmuş, 2013b; Erdem, Gün ve Sever, 2015; Göçer, 2017a; Göçer, 2017b; Gün, 2013a; Gün, 2013b; İşcan, 2011; İşcan, 2017; Melanlıŏ̆lu, 2013a; Melanlığlu, 2013b; Melanlığlu, 2013c; Uysal, 2019; Yılmaz ve Kocaoğlu, 2017. Bu çalışmalar incelendiğinde, çalışmaların genellikle tek bir öğretim yöntemi üzerinde derinlemesine bilgi verdiği ya da farklı dil öğretim yöntemleri üzerine ayrıntıya inilmeden genel bilgi verdiği görülmektedir. Bununla beraber, her bir dil öğretim yöntemi için öğretmen-öğrenci rollerine değinen ve yöntemlerin olumlu-olumsuz özelliklerini sunan bir çalışmaya rastlanmamıştır. Bir bütünlük içinde dil öğretim yöntemlerinin tümüne öğretmen-öğrenci rolleri açısından ve olumlu-olumsuz özellikler açısından bir bakış, Türkçeyi yabancı dil olarak öğretenlere, dil öğretim sürecinde yöntem seçimi konusunda yol gösterici olmak bakımından önemlidir. Bu bağlamda çalışmada dil öğretim yöntemlerinde öğretmen-öğrenci rollerinin ve yöntemlerin olumlu-olumsuz özelliklerinin neler olduğunu sunmak amaçlanmıştır.

\section{Yöntem}

Türkçenin yabancı dil olarak öğretiminin etkililiğini arttırmak adına, dil öğretim yöntemlerindeki öğretmen-öğrenci rollerini ve yöntemlerin olumlu-olumsuz özelliklerini ortaya koymayı amaçlayan bu çalışma, literatür çalışmasına dayalı bir derleme çalışmasıdır. Bu bağlamda, benzer konularda ortaya konulmuş çalışmaların içeriğine ulaşılmış ve dil öğretiminde sıklıkla kullanılan yöntemlerin neler olduğu incelenerek bununla ilgili kuramsal bir alt yapı hazırlanmıştır. Literatür çalışması doğrultusunda dil öğretiminde kullanılan yöntemlerdeki öğretmen-öğrenci rolleri ve yöntemlerin olumlu-olumsuz özellikleri derlenmiş ve bir bütün hâlinde sunulmuştur. Bu bağlamda, çalışmada, alan yazında yer alan yöntemlerdeki öğretmen-öğrenci rollerinin ve yöntemlerin olumlu-olumsuz özelliklerinin açıklama ve uygulama örneklerine yer verilmiştir. 


\section{Dil öğretim yöntemleri ve öğretmen-öğrenci rolleri}

Dil öğretim yöntemi, bir dil öğretim yaklaşımıyla ilgili olan ve dil özelliklerinin düzenli sunulması amaciyla izlenen bir yol, bir öğretim unsurudur (Demircan, 2013; Memiş ve Erdem, 2013). Türkçenin yabancı dil olarak öğretimi söz konusu olduğunda dil öğretim yöntemlerini bilmek öğretimcilere, dil öğretim sürecinde sınıf içinde yapılacaklar açısından yardımcı olacaktır.

Bu bölümde, dil öğretiminde kullanılan yöntemler hakkında kısaca bilgi verilip yöntemlerdeki öğretmen ve öğrenci rolleri üzerinde durulmuştur.

\subsection{Dil bilgisi-çeviri yöntemi (grammar-translation method) ve öğretmen-öğrenci rolleri}

Dil Bilgisi-Çeviri yöntemi geçmişten günümüze dil öğretiminde sıklıkla kullanılan dil öğretim yöntemlerinden biridir. Dil öğretiminde dil bilgisi kurallarını öğretmeyi önceleyen ve çeviri tekniğini kullanan yöntemin Durmuş'un (2013a: 51) belirttiği gibi Avrupa'da orta dereceli okullarda kullanılmak üzere ortaya çıktığı ve geliştiği düşünülmektedir.

Celce-Mursia (2001: 6) Dil Bilgisi-Çeviri Yöntemi’nin özelliklerini şöyle açıklamaktadır:

Öğretim, öğrencilerin ana dilinde verilmektedir.

İletişim için hedef dilin çok az kullanımı vardır.

Odak nokta, sözcüklerin biçim ve çekimlerini incelemek gibi dil bilgisel inceleme üzerinedir.

Zor metinlerin erken okunması vardır.

Tipik bir alışırma, cümleleri hedef dilden ana diline ya da ana dilinden hedef dile çevirmektir.

Öğretmenin hedef dili konuşması gerekmemektedir.

Dil Bilgisi-Çeviri Yöntemi’nde, hedef dilde iletişim kurmak amaçlanmadığından sınıf ortamında ana diline yer verilmektedir. Metinlerin okunup çeviri yapılması; dil bilgisi yapılarının çalışılması; dilin işlevlerine yönelik kuralların ezberlenmesi; fiil çekimlerinin öğrenilmesi gibi dil bilgisi ağırlıklı etkinlikler bu yöntemin kullanıldığı derslerin odak noktasını oluşturmaktadır. Eğitim süreci, uzun ve karmaşık metinleri okumayı ve doğrudan çevirmeyi; metin parçalarını ve kurallarını ezberlemeyi içermektedir.

Sınıfta kullanılan materyaller arasında metin, sözlük ve dil bilgisi kitabı önemli bir yer tutmaktadır. Derslerde dilin kendisini (kullanımını) öğrenmek değil, dil hakkında (teorisini) öğrenmek söz konusu olmuştur. Böylece dil öğrenmek için harcanan zaman dilin kullanımı için değil, dilin teorisini öğrenmeye harcanmaktadır.

Dil Bilgisi-Çeviri Yöntemi’nde öğretmenin rolü merkezidir, öğretmen otoritedir. Yöntem dil bilgisi ve çeviri temelli olduğundan öğretmen ana dilinin dil bilgisi kurallarını iyi biliyor olmalıdır. Yöntemde, öğrenenler ise öğretmeni model almak, dil bilgisi kurallarını ezberlemek ve alıştırmaları doğru bir şekilde yapmak rolündedir (Şenel, 2015: 32).

\subsection{Doğrudan yöntem (the direct method) ve öğretmen-öğrenci rolleri}

Dolaysız Yöntem, Düzvarım Yöntemi ya da Berlitz Yöntemi olarak da anılan Doğrudan Yöntem ile sınıfta, öğretim ve iletişim dili olarak hedef dilin kullanılmasıyla, ana dilinin ve çeviri tekniğinin kullanımından uzak durulmasıyla, Dil Bilgisi-Çeviri Yöntemi bir kenara bırakılmış ve radikal bir değişim 
yoluna gidilmiştir (Liu ve Shi, 2007: 70). "Öğrenilen dil ile yaşam arasında doğrudan ilişki kurularak öğrenme yolu” bu yöntemi yansitmaktadır (Demircan, 2013: 195).

Li'ye göre (2012: 166) bu yöntemin savunucuları dilin örnekleme/gösterme ve hareket yoluyla/yaparak öğretilebileceğini öne sürmüşlerdir. Bu da demektir ki öğretim ve iletişim dili olarak hedef dil kullanılır. Bu yöntemde telaffuza da önem verilir. Dil bilgisi ise tümevarım ile öğretilir.

Öğretmenin model olduğu bu yöntem, büyük ölçüde öğretmenin enerjisine dayanmaktadır. Bu sebeple de öğretmen sınıf etkinliklerini yönlendiren, çok iş yapan ve yorulandır. Öğretmen ana diline başvurmadan anlamı farklı yollarla açıklamak durumundadır (Demirel, 2012; Larsen-Freeman ve Anderson, 2011; Tosun, 2006). Bu yöntemde öğrenenin rolü Dil Bilgisi-Çeviri Yöntemi’ne göre daha az pasiftir. Öğrenen aktif olmalı ve en kısa zamanda hedef dilde düşünmeyi öğrenmelidir. Bu sebeple, bu yöntemden daha çok tümevarım yeteneği gelişmiş öğrenenler yararlanacaktır (Demircan, 2013; Demirel, 2012; Larsen-Freeman ve Anderson, 2011).

\section{3. İşitsel-dilsel yöntem (audio-lingual method) ve öğretmen-öğrenci rolleri}

Kulak Dil Alışkanlığı, Ordu Yöntemi gibi isimlerle de anılan İşitsel-Dilsel Yöntem, 2. Dünya savaşına katılan Amerika Birleşik Devletleri'nin Amerikan Ordusu'nun ihtiyaçlarını hızlı ve etkili bir şekilde karşılamak için ortaya çıkmıştır.

$\mathrm{Bu}$ yaklaşımda, "İşitsel-Dilsel” terimi iletişim sürecinin iki bileşenine göndermede bulunmaktadır. Yöntemde, "İşitsel" dinlemeye vurgu yaparken, "dilsel" konuşma becerisini öne çlkarmaktadır (AbuMelhim, 2009: 39). Bir başka deyişle yöntem, konuşma ve dinlediğini anlamaya öncelik vermektedir (Calp, 2007; Demircan, 2013). Yöntem, bir dizi diyaloğun ezberlenmesi ve dil yapılarının somut olarak uygulanmasını içermektedir. Dil bilgisi açıklamasına gerek duyulmadan diyalogların uygulanmasının, sözlü dil yeterliliğini geliştirdiğine inanılmaktadır.

İşitsel-Dilsel Yöntem ile dil öğretimi, alışkanlık oluşturma anlamına gelmektedir. Söz konusu yöntem, cümle yapıları ve bu yapıların telaffuzlarıyla ilgili mekanik alıştırmalarla öğretim üzerine kurulmuştur. Asıl amaç öğrenenlere kısa süre içerisinde iletişimsel beceri kazandırmak, cevap verme işini otomatikleştirmek ve alışkanlık hâline getirmektir (Ekawati, 2017: 62). Buna göre bu yöntemde dil, bir dizi alışkanlıktır ve otomatik bir süreçtir. Yaylıya (2011: 15) göre "Alıştırmaların amacı dili konuşanlar kadar çabuk yanıt vermeyi sağlamaktır.”.

Bu yöntemin belki de en önemli özelliği, dil becerilerini bir sıraya koymasıdır: Dinleme, konuşma, okuma, yazma. Bu beceri hiyerarşisi, öğrencilerin diğer dil becerilerinden birini geliştirmeden önce hedef dilde dinleme yapması gerektiğini öne sürmektedir. Teoriye göre, öğrenenler söylenilenleri duymaya gerçekten dikkat etmek zorunda olduklarından, iyi bir dinleyici ve nihayetinde iyi bir konuşur olacaktır. Öğrencilerin ancak bu şekilde, telaffuz ve tonlama gibi dilbilimsel özellikleri içselleştirme şansları olacaktır. Bu da öğrenenleri daha etkili konuşurlar hâline getirecektir (Abu-Melhim, 2009: 42). Siralamanın önemli olduğu diğer bir alan da tekrar eden alıştırmalarla her seferinde bir tane olacak şekilde, öğretilen yapıların öğretimidir (Abu-Melhim, 2009: 42). İşitsel-Dilsel Yöntem'e dair söylenenlere ek olarak, bu tür öğretim süreçlerinde ana dilinin çok küçük bir rolü vardır. Burada, öğretmen ana dili çok az kullanır ve benzer şekilde öğrencilerin ana dillerini kullanmalarına da çok az izin verir (Abu-Melhim, 2009: 42). Dersler esnasında esas olarak hedef dil kullanılır (Ekawati, 2017: 
62). İşitsel-Dilsel Yöntem'de sözcüklerin sınırlandırıldığı; dilbilimsel ve kültürel bir bağlamda öğretildiği görülmektedir (Demirel, 2012; Ekawati, 2017; Yaylı ve Yaylı, 2011).

Öğretmenler süreç içerisinde merkezdedir ve yol gösterici rolünü üstlenirler. Öğretmenlerin hatasız bir şekilde konuşmaları gerektiğinden işleri oldukça zordur. Otomatikleşmiş cevapların haricinde, hatasız cümleler kurmak için çok çaba sarf edilir (Ekawati, 2017: 62). Bu sebeple yöntem, öğretmenden çok hazırlık yapmasını bekler (Calp, 2017: 620). Bu süreçte öğretmenin en önemli görevlerinden biri yanlışların kalıcı olmaması için öğrenenlerin sesletim ve yapı yanlışlarını, doğru kullanımı anında tekrar etmek suretiyle düzeltmektir (Bölükbaş, 2013a: 64). Bu bağlamda öğretmen, iyi bir model olmaktan sorumlu olan; öğrenenlerin dil davranışını kontrol eden ve yönlendiren bir orkestra şefi gibidir (LarsenFreeman ve Anderson, 2011: 76). Bu yöntemde, öğretmen hedef dili modeller. Öğrenmenin hızını ve yönünü kontrol eder, öğrenenlerin performanslarını düzeltir ve gözler. Öğretmen, alıştırmaları (mekanik alıştırma), görevleri çeşitlendirerek ve dil yapılarını pratik etmek için uygun durumlar seçerek öğrenenlerin derse katılımlarını sağlar. Bu yöntemde dil öğrenimi, öğretmenle öğrenen arasındaki aktif sözel iletişim sonucu ortaya çıkar. Öğrenememe, sadece metodun yanlış uygulanmasından ortaya çıkar; örneğin öğretmenin yeteri kadar pratik imkânı sunmaması ya da öğrenenin gerekli olan yapı ya da kalıpları ezberleyememesinden ortaya çıkar. Ama metodun kendisi hiçbir zaman suçlanmaz (Richards and Rodgers, 2002: 62).

Öğrenenler, öğretmenin modellik yapmasının veya model konuşmacılardan sağladığı ses kayıtlarının taklitçileridir. Öğrenenler, öğretmenin talimatlarına uyar; mümkün olduğunca doğru ve hızlı bir şekilde cevap verirler (Larsen-Freeman ve Anderson, 2011: 76). Öğrenenler, doğru cevaplar üretmeleri için, eğitim teknikleri sayesinde doğru cevaplar vermeye yönlendirilebilecek organizmalar olarak görülür (Belli eğitici teknikler sayesinde öğrenciyi doğru cevap vermeye yönlendirebilirsiniz.). Davranışçı öğrenme teorisine paralel olarak öğretim, öğrenmenin içsel süreçlerinden ziyade dışadönük hâline odaklanır. Öğrenen, uyarana karşllık vererek tepkisel bir rol oynar. Böylece öğrenenin içerik, öğrenme hızı ya da stili üzerinde çok az rolü vardır. Öğrenenler, bir etkileşim başlatma konusunda teşvik edilmezler. Çünkü böyle bir durum hatalara sebebiyet verebilir. Öğrenenlerin, öğrenme sürecinin ilk aşamalarında tekrar ettikleri şeyin anlamını bilmemeleri bir dezavantaj olarak görülmez. Çünkü öğretmeni dinleyerek, birebir doğru bir şekilde taklit ederek, karşllık vererek ve kontrollü verilen görevleri yerine getirerek sözel davranışın yeni bir formunu öğrenirler (Richards and Rodgers, 2002: $62)$.

\subsection{Sessiz yol (the silent way) yöntemi ve öğretmen-öğrenci rolleri}

Caleb Gattegno bu yöntemi, yine bu yöntemin altında yatan bazı gözlemler üzerine kurmuştur (Young, 2000: 546): "İlk olarak, öğrenenler, öğretmen bir şey öğrettiği için öğrenmezler. Bu da demektir ki eğer öğretmenler sınıfta ne yapmaları gerektiğini bilmek istiyorsa, öğrenme işi ve öğrenenler üzerine çalışmaları gerekir. Bunu gerçekleştirmek için de kişinin kendisini öğrenen konumuna koymasından daha iyi bir yol yoktur. Gattegno kendisini, öğrenen yerine koyup incelediğinde fark etmiştir ki insanlara, sadece farkındalık öğretilebilecek bir şeydir. Bu sebeple bu yöntem bilgi vermekten çok farkındalık oluşturma üzerine kurulmuştur. Diğer öğrenenleri incelediğinde, bu öğrenenlerin sınıf ortamında görülebileceklerden daha zorlu uğraşlar konusunda uzmanlaşmada ömür boyu başarıyı, azmi ve bilgi ihtiyacını kendi öğrenme süreçlerine dâhil eden yetenekli, bağımsız ve güçlü insanlar olduklarını görmüştür. Bu durumun, öğrenenlerin yaşına bakmaksızın, eğitim açısından normalin altında kabul edilen ya da psikolojik olarak zarar görmüş kişiler bile olsalar doğru olduğunu görmüştür. Gattegno bir öğretmen olarak sınıfta bulunma şekli ve sunduğu etkinliklerin, bu sınıfta bulunma şeklini ya 
desteklediğini ya da zayıflattı̆̆ını görmüştür. Sessiz Yol yönteminde kullanılan düzeltme tarzı, öğretmenin sessizliği gibi tekniklerin çoğu bu anlayıştan doğmuştur. Burada öğretmenin sessiz kalmak için hiç konuşmaması gerektiğinin anlaşılmaması gerekir. Basitçe şöyle söylenebilir; öğretmen hiçbir zaman örnekleme yapmaz ve öğrencilerin kendi kendilerine bulabilecekleri cevapları vermez. İkinci olarak, dil genellikle bir iletişim aracı olarak tanımlanır. Dil bazı zamanlarda bu şekilde işleyebildiği gibi, Gattegno'nun gözlemlerine göre bu durumun böyle olması tahmin ettiğimizden çok daha az sıklıktadır. Bunun sebebi de dilin, konuşucuların karşlarındaki dinleyiciler konusunda duyarlı olmalarını ve düşüncelerini yeterli bir şekilde ifade edebilmelerini gerektirmesidir. Diğer bir sebep de dilin, konuşucularının bir karşlık vermeden önce kendilerini mesaja vermelerini gerektirmesidir. Bu konular üzerine çalışmak çoğunlukla dil öğretim sınıfının sınırları dışındadır. Öte yandan, dil hemen hemen her zaman için duygu, düşünce, algı ve fikirlerin ifade edilmesinde kullanılan bir araçtır ve öğrenciler öğretmenleriyle bunlar üzerine oldukça etkili çalışmalar gerçekleştirebilirler. Üçüncü olarak, Gattegno'nun yaklaşımında kriter geliştirmeye önem verilir. Bilmek demek, neyin doğru neyin yanlış, neyin kabul edilebilir neyin kabul edilemez, neyin yeterli neyin yetersiz olduğuna dair kriter geliştirmiş olmak demektir. Kriter geliştirmek, verilen iki nokta arasındaki sınırları keşfetmekle ilgilidir. Bu da demektir ki hata yapmak öğrenmenin önemli bir parçasıdır. Öğretmenler bunu, kendi hayatlarında kendilerini benzer bir durumda gözlemleyerek, anladıklarında yapılan hataları Gattegno'nun deyişiyle “ders için kıymetli” olarak göreceklerdir. Hatalara karşı böyle bir tutum sergilemek öğrencilerin yeni dilin işleyişi üzerine daha cesur ve sistematik keşifler yapmalarına olanak sağlar. Bu süreç hız kazandıkça öğretmenin rolü öncülük etmekten çok hızlı kaynak ve dil kullanımı konusunda denemeler yapan öğrencilere doğru geri dönüt veren hâline gelir. Sessiz Yol yönteminin kullanıldığı bir sınıfta öğretmenin ne yapacağını belirleyen dördüncü unsur da bilginin kendiliğinden "nasıl yapılacağını bilmek" hâline gelmediğidir. Bu, kayak yapmayı ya da piyano çalmayı öğrenirken belirgin bir şekilde görülebilir. Bir insanı kayak yapabilir hâle getiren manevra ile ilgili fizik kuralları ya da karın kimyasından çok kayma işinin kendisidir. Bu durum dil öğrenirken de geçerlidir. Nasıl konuşulacağı bilgisini oluşturmanın yolu, o dili konuşmaktır.”.

Bu yöntem, öğrenime ve öğrenmeyi öğretmeye önem vermektedir (Demircan, 2013; Erdem, Gün ve Sever, 2015). Bu yöntemde, öğrenme sürecini destekleyen üç faktör vardır: Öğrenenlerin keşfetme süreçleri, somut nesnelerin sürece katkısı ve problem çözme. Gattegno'nun hipotezine göre öğretmen önce bir nesneyi göstermeli, ardından öğrencilerin buna verdikleri karşllıkları sessiz bir şekilde yönlendirmelidir. Son olarak öğretmen, öğrenciler birbirleriyle etkileşime geçtiğinde aradan çekilmelidir (Li, 2012: 167).

Bu yöntemde renk çubukları ile posterler kullanılmaktadır. Sessiz Yol öğretmeni olmayı öğrenmek için çizelge üzerindeki kelimelerin konumlarını ve hangi rengin hangi sese denk geldiğini bilmek gerekir. Ancak bu bilindiği zaman gerçek iş başlar. Sessiz Yol öğretmenleri, öğrencilerin farkındalıklarını daha net görebilmek için kendi öğrenme süreçlerindeki farkındalığın rolünü kavramalıdırlar. İnsan olarak kendileri üzerinde daha derin bir farkındalığa ulaşmak için kendi kendine keşfetme işini çok ciddiye almaları gerekir. Sonrasında Sessiz Yol'un temelinde yatan diğer bir ilkeyi (öğrenciler dil üzerinde çalışırken, öğretmen öğrenciler üzerinde çalışır) uygulamaya başlayabilirler (Young, 2000: 548). Öğretmen çok etkin değildir. Öğrenciler dili pratik edebilsin diye ufak tefek değişiklikler sunabilir. Öğrenciler git gide dil konusunda daha meraklı hâle gelirler ve dili etkin bir şekilde keşfetmeye başlarlar. Bir şeyin "şu şekilde" ya da "bu şekilde" de kullanılıp kullanılmayacağını öğrenmek amacıyla kendileri de değişiklikler sunar. Bunu yaparken de daha önce keşfettiklerini kullanıp yine bunların üzerine bir şeyler koyarlar. Bundan sonra öğretmen dersin içeriğiyle ilgili sorumluluğu aşamalı olarak öğrencilere verebilir. Yine de, öğrenme süreci için gerek duyulan geri dönütü sağlamayı bırakmaz. Böylelikle dersin 
içeriği öğrencilerin istediği neyse o olur. Bu da çoğunlukla kendi hayatları, düşünceleri, duygu ve fikirleri üzerine keşiflerdir (Young, 2000: 548). Sessiz Yol öğrenenleri, öğretmeni izlemek ve anlamak, söylenenleri yapmak ve öğrenenler arasında etkileşimde bulunarak söze katılmakla yükümlüdür (Demircan, 2013: 242). Bu yöntemde, öğrenenler kendi öğrenmelerinden sorumludur.

\subsection{Grupla/danışmanlı dil öğretim yöntemi (community language learning method) ve öğretmen-öğrenci rolleri}

Yöntemde geleneksel sınıf ortamına, öğretmenin otorite olmasına, öğrenenlerin hata yapma korkusu ve kaygısı yaşamasına karşı çıkılarak iş birliğine dayalı sosyal bir öğrenme süreci oluşturulmak istenmiştir (Bölükbaş, 2013b; Erdem, Gün ve Sever, 2015; Li, 2012). Yöntem, ayrıca dilin etkileşimli bir görünümünü de içermektedir. İki tür etkileşim vardır, öğrenenlerin kendi arasında ve öğrenenler ile bilginin kaynağı olan öğretmen arasında. Öğrenen ile öğretmen arasındaki ilişki, danışan ile danışman arasındaki ilişki ile karşılaştırılır. Öğrenenler, bağımlı olma hâlinden bağımsız olma hâline doğru çocukların gelişimine paralel bir gelişim dönemi geçirecektir (Li, 2012: 167).

Öğretmenin ilk rolü bir danışmanlıktır (Larsen-Freeman ve Anderson, 2011: 133). Öğrenmenin ilk aşamalarında öğretmen, hedef dil çevirileri ve öğrenenlerin isteği üzerine taklit için bir model sağlayarak destekleyici bir rol üstlenir. Daha sonra, öğrenciler tarafından etkileşim başlatılabilir ve öğretmen, öğrencinin konuşmalarını izler ve talep edildiğinde yardım sağlar. Öğrenme ilerledikçe, öğrenciler eleştirileri kabul etme konusunda giderek daha fazla yetenek kazanırlar ve öğretmen doğrudan sapma sözlerini düzeltmek, deyimler sağlamak, dil bilgisinin kullanımı ve ince noktaları hakkında tavsiyelerde bulunmak için doğrudan müdahale edebilir. Öğretmenin rolü başlangıçta besleyici bir ebeveyne benzetilmektedir (Richards and Rodgers, 2002: 95). Öğrenciler bir topluluğa üye olurlar - kendi arkadaşları ve öğretmenleri - ve toplulukla etkileşim kurarak öğrenirler. Öğrenme bireysel bir başarı olarak değil, işbirlikçi olarak gerçekleştirilen bir şey olarak görülür. Bu yöntem öğrencileri, genellikle altı ile on iki öğrencinin bulunduğu bir çevrede gruplandırır. Grup başına ya da öğrenci başına bir danışman düşebilir (Richards and Rodgers, 2002: 94). Başlangıçta, öğrenci öğretmene çok bağımlıdır. Bununla birlikte öğrenci öğrenmeyi sürdürdükçe, öğrencinin giderek bağımsızlaştığı fark edilir. Grupla Dil Öğrenme metodolojistleri bağımlılıktan bağımsızlığa uzanan bu akışta beş aşama belirlemişlerdir. Birinci, ikinci ve üçüncü aşamalarda öğretmen dil üzerinde odaklaşmanın yanında öğrenenlerin öğrenme süreçlerini destekleyici olmaya da odaklanır. Dördüncü aşamada, öğrenci düzeltmelerden yararlanmaya hazır bulunduğundan ve dilde tam bir güvenlik hissettiğinden artık öğretmen "doğruluk" üzerinde yoğunlaşır. Doğruluğun daima ilk üç aşamada bile bir odak olduğuna dikkat edilmelidir. Bununla birlikte doğruluk, akıcıllğa göre ikinci derecededir. Dördüncü ve beşinci aşamalarda ise ön planda olan doğruluktur (Larsen-Freeman ve Anderson, 2011: 133).

\section{6. İşbirlikli öğrenme yöntemi (cooperative learning method) ve öğretmen-öğrenci rolleri}

Öğrenenlerin öğrenme sürecine aktif olarak katıldığı, öğrenenlerin grup arkadaşlarının öğrenmelerinden de sorumlu olduğu yöntemde (Batdı, 2013) öğrenenler, 2-4 kişilik gruplarda birlikte çalışırlar. İşbirlikli Öğrenme Yöntemi’nde kullanılabilecek uygulama ve etkinlik örnekleri içinde öğretmen-öğrenci rolleri Olsen ve Kagan'dan (1992: 88) hareketle şöyle özetlenebilir: 
Üç Aşamalı Röportaj: Öğrenenler, ikili olarak biri görüşmeci, biri görüşme yapılan kişi olarak çalışırlar. Daha sonrasında rolleri tersine çevirirler. Öğrenenler, iki görüşme esnasında öğrendiklerini ekip üyeleriyle paylaşır.

Yuvarlak Masa: Oluşturulan gruplara bir kâğıt ve kalem verilir. Bir öğrenen, ilgili konuyla ilgili yazacaklarını kâğıda ekledikten sonra kalemi solundaki öğrenene verir. Her öğrenen sırasıyla katkıda bulunur. Bu etkinlik sözlü olarak yapılırsa "Round Robin” adını alır.

Düşünce Eşi Paylaşımı: Öğrenenler, öğretmenin sorduğu sorunun cevabını düşünerek cevaplarını bir arkadaşıyla paylaşırlar. Ardından öğrenenler, eşlerinin cevaplarını sınıfla paylaşırlar.

Çözme Eşleme Paylaşımı: Öğretmenin ortaya koyduğu bir soruna yönelik öğrenenler ayrı ayrı çözümler üretirler. Öğrenenler röportaj, yuvarlak masa, Round Robin etkinlikleriyle çözümlerini paylaşırlar.

Numaralı Başlıklar: Öğrenenler gruplara ayrılır. Öğretmenin sorduğu soruyu grup içinde çalışırlar. Grup içindeki herkesin, cevabı bildiğinden emin olurlar. Öğretmen bir sayı söyler ve o sayıdaki öğrenen cevabı açlklar.

İşbirlikli Öğrenme Yöntemi’nde, öğretmenin rolü, geleneksel öğretmenlerin rolünden oldukça farklıdır. Öğretmen sınıfta, hedef belirleme, görevleri planlama ve yapılandırma, sınıfın fizikî düzenlemesini oluşturma, öğrencileri gruplara ayırma ve roller verme; materyalleri ve zamanı seçme gibi oldukça yapılandırılmış ve iyi örgütlenmiş bir öğrenme ortamı yaratmalıdır (Johnson ve diğerleri, 1994'ten aktaran Richards and Rodgers, 2002: 199-200). Bu bağlamda öğretmen için önemli bir rol, öğrenmeyi kolaylaştırmasıdır. Bu yöntemde, öğretmenler daha az konuşurlar. Düşünmeyi sağlamak için sorular sorarlar, öğrencileri gerçekleştirecekleri görevlere hazırlarlar, öğrencilerin öğrenme görevlerine yardımcı olurlar ve daha az disiplin kontrolü getiren az komut verirler (Harel, 1992). İş Birlikli Öğrenme Yöntemi’nde öğrenenin birincil rolü, diğer grup üyeleriyle görevlerde işbirliği içinde çalışması gereken bir grubun üyesi olarak bulunmaktır. Öğrencilerin ekip çalışması becerilerini öğrenmesi gerekir. Öğrenciler aynı zamanda kendi öğrenmelerinin yöneticileridir. Yaşam boyu öğrenme becerilerinin bir birleşimi olarak görülen kendi öğrenimlerini planlamak, izlemek ve değerlendirmek öğretilir. Böylece öğrenme, öğrencilerin doğrudan, aktif katılımını ve dâhil olmasını gerektiren bir şeydir. Eşli çalışma, her iki öğrenicinin de öğrenme işleriyle uğraşmak için harcadığı maksimum süreyi sağlayan en tipik İşbirlikli Öğrenme biçimidir. Öğrencilerin alternatif rolleri olduğu eşli görevler, öğretmenler, denetleyiciler, kaydediciler ve bilgi paylaşanlar rolündeki ortakları içerir (Richards and Rodgers, 2002: 199). Bir başka deyişle, grup ürünlerinin ve raporlarının oluşmasında gruptaki herkesin eşit katılımı gerektiğinden öğrenenler yazıcı, sözcü, okuyucu gibi rol dağılımları yaparlar ve her öğrenci rolünü ya da kendisine düşen sorumluluğu yerine getirir (Bölükbaş, 2013c: 73).

\subsection{Telkin yöntemi/esinlemeli yöntem (suggestopedia) ve öğretmen-öğrenci rolleri}

Dil öğretiminde neyin öğretildiğinden çok nasıl öğretildiğine önem veren yöntemde, öğrenme süreci öğrencilerin rahat hissettikleri bir ortam içinde gerçekleşir (Güçlü, Arslan ve Üstünyer, 2017; Li, 2012). Yöntemin dil öğretimine yaptığı en büyük katkı, sınıf içi iletişimin rahat bir ortamda yapılması ve dil bilgisi yerine yaparak yaşayarak öğrenmeye önem vermesidir (Akpınar Dellal ve Akbay Pişkin, 2015; Demirel, 2012).

Hem öğretme kabiliyeti hem de iletişim yeteneği üst düzeyde olan öğretmenin öncelikli rolü, öğrenenleri telkin için en uygun duruma getirmek ve dil malzemesini uygun bir şekilde sunmaktır (Akpınar Dellal 
ve Akbay Pişkin, 2015; Richards and Rodgers, 2002). Bu süreçte öğretmen tamamen tekrar yapmadan öğrenenlere yardımcı olur. Gerektiğinde ana dilinde çeviriye yer verebilir (Çelik, 2013: 92). Öğrenenlerin öğrenme sürecinde öğrendiklerini, yapabildiklerini hissetmeleri önemlidir. Öğrenenlerin öğrenebileceklerinin farkında olup bunu hissetmeleri Telkin Yöntemi'nin temel ilkelerindendir. Yönteme göre öğrenen, bunu hissederse öğrenecektir. Li'ye (2012: 168) göre bu yöntemde öğretmen otoriter konumdayken öğrenenler, çocuk/bebek durumundadırlar. Böylelikle öğrenenler, tekrar özgüven kazanırlar. Telkin Yöntemi’ne göre öğrenenler, aynı hızda öğrenirler. Gerekli koşullar sağlandığında öğrenemeyecek öğrenci yoktur (Erdem, Gün ve Sever, 2015: 562). Ancak öğrenenlerin zihinsel durumu başarı için önemlidir, bu sebeple öğrencilerin zihinlerini karıştıran nitelik ve çeldiricilerden uzak durmaları gerekmektedir. Öğrencilerin daire şeklinde oturmaları, yüz yüze iletişimi ve etkinliklere katılımı sağlar (Richards and Rodgers, 2002: 103-104).

\subsection{Tüm (toplu) fiziksel tepki yöntemi (total phsycal response method) ve öğretmen- öğrenci rolleri}

Dinleme ve anlama becerilerinin vurgulandığı yöntem, öğrenenlerin dil girdisine maruz kalmasına önem veren bir yöntemdir. Derslerde çoğunlukla ses ve beden dili kullanılır (Demircan, 2013; Ekawati, 2017; Larsen-Freeman ve Anderson, 2011). Yöntemde, hareket etmek hafızayı geliştiren bir teknik olarak bulunur ve ders süresince emir kipi kullanılır (Widodo, 2005). Bu yöntem önemli olanın, öğrencileri, öğretmenlerinden gelen hedef dildeki sözlü emirleri dinleyip bunlara cevap verme konusunda teşvik etmek olduğunu öne sürer. Diğer bir deyişle, Tüm Fiziksel Tepki Yöntemi konuşma ve eylem üzerine kurulu bir yöntemdir. Dili fiziksel (motor) eylemler aracilığıyla öğretmeyi hedefler (Widodo, 2005: 237). Bu yöntem sinfta uygulanacağı zaman, bir öğretmenin modellemesine ihtiyaç duyulur. Modellemenin çok önemli üç özelliği vardır: 1. Konuşmaya başlamadan önce sözlü dili iyice kavramak gerekir, 2. Anlama işi vücut hareketleriyle geliştirilir ve 3. Dinleme süreci öğrencilerin konuşmaya hazır hâle gelmelerine yardımcı olur. Bu modellemede öğrenciler konuşmaya zorlanmaz. Bu yöntemin kısa periyotlar hâlinde uygulanması tavsiye edilir. Aksi takdirde, öğrenciler bu yöntemle öğrenmekten dolayı yorgun düşebilir (Widodo, 2005: 247).

Öğretim sürecinin başında öğretmen, öğrenen davranışlarını yönlendiren kişidir (Larsen-Freeman ve Anderson, 2011: 149). Bu yöntemde, öğretmen aktif bir rol oynar. Öğretmen ne öğretileceğine karar veren, yeni materyalleri sunup modelleyen ve sınıfta kullanılacak ek materyalleri seçen kişidir. Asher'n (1977: 47) belirttiğine göre öğretmenlerin sinıfta kullanacakları cümleleri özellikle de özgün cümleleri yazmaları, plan yapmaları akıllıca olur çünkü derste anlık olarak bunları yapmak mümkün olmaz. Ancak Asher (1977) öğretmenin rolünün öğretmek işinden ziyade öğretme firsatları olduğunu vurgular. Öğretmenin sorumluluğu, öğrenciler hedef dilin temel kurallarını içselleştirebilsinler diye dile mümkün olan en iyi şekilde maruz kalmalarını sağlamaktır. Böylelikle, öğretmen öğrenenlerin aldıkları dil girdisini, öğrencilerin kendi zihinlerinde yapılandıracakları "bilişsel-kavramsal harita (cognitive map)"ya ham malzeme sunarak kontrol eder. Öğretmen, öğrencilerin kendi doğal hızlarında konuşma becerilerini geliştirmelerine imkân tanımalıdır. Öğretmen öğrenenlere, ailenin çocuğuna dönüt vermesi gibi dönüt vermelidir. İlk zamanlarda, anne-babalar çok az şeyi düzeltirler ama çocuk büyüdükçe konuşma konusunda aileler daha az hatayı tolere ederler. Benzer olarak öğretmenler, ilk zamanlarda çok fazla düzeltme yapmaktan kaçınmalılardır. Hataları düzeltmek için öğrenenlerin konuşmalarını bölmemelilerdir. Çünkü konuşmanın bölünmesi öğrenenleri engeller. Ancak zamanla öğrenenlerin konuşması iyileştikçe hatalar konusunda daha çok öğretmen müdahalesi beklenir (Richards and Rodgers, 2002: 76). Öğrenenler, öğretmeni taklit ederler (Larsen-Freeman ve Anderson, 2011: 149). Bu yöntemde, öğrenenlerin birinci rolleri dinleyici ve uygulayıcıdır. Dikkatli bir şekilde dinlerler ve 
öğretmen tarafından verilen komutlara fiziksel olarak tepki verirler. Öğrenenlerden daha önce öğrenmiş oldukları şeylerin farklı ve özgün kombinasyonlarını anlamaları ve bunlara tepki vermeleri beklenir. Öğrencilerin kendilerinin de farklı ve özgün kombinasyonlar üretmeleri beklenir. Öğrenenler, kendi gelişimlerini kendileri gözlemler ve değerlendirir. Öğrenenler konuşmaya hazır olduklarında, konuşmaları konusunda cesaretlendirilirler. Yani öğrenenler, dilde yeterli bir temel içselleştirdiklerinde konuşmaları konusunda cesaretlendirilirler (Richards and Rodgers, 2002: 76).

\title{
3.9. Görsel-işitsel yöntem (audio-visual method) ve öğretmen-öğrenci rolleri
}

Dil öğretimine görselliği ve işitselliği dâhil eden yöntem, Gün'ün (2013b) belirttiği gibi İngilizceye karşı Fransızcanın yabancı ülkelerdeki yerini korumak için yapılan çalışmalardan doğmuştur. Yöntem, ilk olarak günlük konuşmaların öğretilmesini hedeflemiş, öncelikli olarak dinleme ve konuşma becerisi geliştirilmek istenmiştir. Ardından okuma ve yazma becerilerinin öğretimi de esas alınmıştır (Güzel ve Barın, 2013; Erdem, Gün ve Sever, 2015).

Teknoloji ve materyal kullanımının, dil öğretim sürecine olumlu etkisi olduğundan ve yöntem de bu olumlu etkiyi hedeflediğinden Erdem, Gün ve Sever’in (2015: 558) belirttiği gibi bu yöntem öğretmenlerinin teknolojik araç-gereçleri, beden dilini, jest ve mimiklerini iyi kullanmaları gerekir. Bu yöntemde öğrenenler, yabancı dili sürekli olarak duymakta ve konuşmaktadırlar (Demircan, 2013: 232).

\subsection{0. İletişimsel dil öğretim yöntemi (communicative language teaching method) ve öğretmen-öğrenci rolleri}

Yabancı dil öğretiminde, dil bilgisi kurallarının ağırlıklı olarak öğrenilmesi yerine bunların iletişim içinde kullanılmasını önemseyen İletişimsel Dil Öğretim Yöntemi, Paker’in (2015) belirttiği gibi dünyada en çok kullanılan dil öğretim yöntemi hâlini almıştır. Dört temel becerinin ve iletişim becerisinin geliştirilmesini destekleyen yöntemde, iletişimsel yetiyi kazanmak da önemlidir. Bu şu şekilde açılanabilir:

\begin{abstract}
"İletişimsel yetiyi kazanmak demek, o dilin iletişimsel becerilerini, yani hem konuşma ve yazma gibi yaratıc becerileri hem de dinleme ve okuma gibi edilgen becerileri kavramak, ayrica o dilin konuşulduğu ülkenin kültürünü, yaşam ve hareket tarzlarını, kısaca sosyodilbilim (sociolinguistik) ve pragmatik biliminin öngördüğü (neyin, nerede, ne zaman, kiminle, nasıl, hangi koşullarda konuşulabileceğini öğrenmek gibi) davranış şekilleriyle birlikte o ülkenin insanlarıyla sözlü ve yazılı olarak iletişim kurmayı öğrenmek demek anlamına gelmektedir.” (Edmonson/House, 1993: 82'den aktaran Aktaş, 2005: 93).
\end{abstract}

Howatt (1984: 279'dan aktaran Paker, 2015: 189) İletişimsel Dil Öğretim Yöntemi’ni kuvvetli ve zayıf uyarlama olmak üzere ikiye ayırmıştır. Kuvvetli uyarlanmış biçimde İletişimsel Dil Öğretim Yöntemi "dilin iletişim yoluyla edinileceğini” iddia etmektedir. Böylece sorunun sadece beynimizde var olan dil bilgisini harekete geçirmekten ziyade dilin kendi sistemini geliştirmeyi harekete geçirmek olduğunu vurgular. Yani "öğrenmek için dili kullan” kavramı ön plandadır. Böylelikle tıpkı ana dili edinme sürecinde olduğu gibi dil bizim için bir öğrenme ve toplumda var olma amacı ve aracıdır. Zayıf uyarlanmış biçiminde ise "dili öğrenenler için iletişimsel amaçla dili kullanmak için çeşitli fırsatların yaratılmasının önemi” vurgulanır. Yani “dili kullanmayı öğrenme” kavramı ön plandadır.

Öğretim sürecinde metne, göreve ve nesneye dayalı ders malzemeleri kullanılır. Bunlar Yaylı ve Yaylı (2011: 18) tarafından şöyle açıklanabilir: "Metne dayalı malzemeler, iletişimsel ortamı sınıf ortamına taşıyabilecek nitelikte hazırlanmış ders kitaplarıdır. Göreve dayalı gereçler ise her türlü oyunlar, görev kartları, ipucu kartları, öğrenci etkileşim uygulama kitapçıkları gibi malzemelerdir. Nesneye dayalı 
gereçleri de gerçek yaşamdan sınıfa taşınmış nesneler oluşturur. Bunlar; gazete ve dergiler, işaretler, ürün paketleri, haritalar, resimler, ilanlar gibi nesneler olabilir.”. Demirel'e (2012: 56) göre gerçekten iletişimsel olan etkinliklerin üç özelliği vardır: Bilgi boşluğu, tercih ve dönüttür. Bunlar şöyle açılanabilir:

"Bilgi boşluğu, bir kişinin, diğerinin bildiğini bilmediği zaman söz konusudur. Eğer iki kişi de bugünün Çarşamba olduğunu biliyorsa '-Bugün günlerden ne? -Çarşamba.' diyaloğu iletişimsel değildir. Tercih, konuşmacı neyi, nasıl söyleyebileceğini tercih edebilir. Eğer alıştırmalar tamamıyla kontrollü ise öğrenciler bir şeyi bir tek yolla söyleyebilirler. Konuşmacının seçme ve bilgi alışverişinde bulunma şansı yoktur, dolayısıyla iletişimsel değildir. Dönüt, gerçek iletişim amaçlıdır. Konuşmacı amacına ulaşıp ulaşmadığını dinleyicisinden aldığı bilgileri değerlendirerek anlar. Ĕğer, dinleyicinin konuşmacıya böyle bir dönüt verme şansı yoksa bu gerçek bir iletişim değildir. Çünkü konuşmacı dinleyiciden karşılık alamaz. Böylece sorunun anlaşılıp anlaşılmadığını değerlendiremez."

Gerçek dünya durumları, iletişimsel etkinlikler, görev temelli çalışmalar, işbirlikli öğrenme ortamları bu yöntemde kullanılmaktadır.

Breen ve Candlin (1980: 99'dan aktaran Richards and Rodgers, 2002: 167) İletişimsel Dil Öğretimi’nde öğretmenin rolünü şöyle açlklamaktadır: Öğretmenin iki ana rolü vardır: Birinci rolü, sınıftaki tüm öğrenenler arasında ve bu öğrenenler ile çeşitli etkinlikler ve metinler arasındaki iletişim sürecini kolaylaştırmaktır. İkinci rolü, öğrenme-öğretme grubunda bağımsız bir katılımcı olarak davranmaktır. $\mathrm{Bu}$ yöntemde, öğretmenlerin iletişim sürecinin kolaylaştırıcısı, öğrenme-öğretme ortamının etkin bir üyesi, düzenleyici, rehber, analist, danışman veya grup süreç yöneticisi olması beklenir ( $\mathrm{Li}$, 2012; Liu ve Shi, 2007; Yaylı ve Yaylı, 2011). Öğretmen sınıfta iletişimi kolaylaştırır. Bunun gibi yapacak birçok rolü vardır. $\mathrm{Bu}$ rolde, öğretmenin büyük sorumluluklarından birisi, muhtemel iletişimi geliştirecek durumları gerçekleştirmektir. Etkinlikler sırasında öğrencilerin sorularını cevaplandıran ve performanslarını izleyen bir danışman gibi davranır. Öğretmen daha sonraki bir zamanda, daha doğru temelli etkinlikler sırasında, onlar üzerinde çalışmak için öğrencilerin hatalarını not edebilir. Diğer zamanlarda, öğrencilerle birlikte iletişimsel aktivitelere katılarak "eş-iletişimci" olabilir (Littlewood, 1981). Bütün bunlardan başka öğrenciler iletişimcidir (communicator). Öğrenciler hedef dil bilgileri tamamlanmamış olduğunda bile, anlamı etkin olarak tartışmaya çalışırlar -bizzat kendileri, anlamı özümsemeye çalışırken başkalarının da onu anlamasına yardım etmeye çalışırlar-. İletişim yoluyla, iletişim kurmayı öğrenirler. Keza öğretmenin rolü öğretmen-merkezli bir yöntemdekinden daha az baskın olduğu için öğrenciler, kendi öğrenmelerinin daha sorumlu yürütücüleri olarak görülürler (Larsen-Freeman ve Anderson, 2011: 165).

Öğretimin öğrenen merkezli ve öğretmenin de bir yön gösterici olduğu (Uysal, 2019: 33) bu yöntemde, Richards and Rodgers'a (2002: 166) göre genellikle süreçte bir metin yoktur, dil bilgisi kuralları sunulmaz, sınıf düzenlemesi standart değildir, öğrenenlerin öncelikle öğretmen yerine birbirleriyle etkileşime geçmeleri beklenir ve hataların düzeltilmesi ya çok azdır ya da hiç yoktur. Kişisellik yerine dayanışmayı savunan bir yaklaşım olduğundan, bu yöntemde öğrenenlerin, başarısız bir iletişimin, konuşmacının ya da dinleyicinin hatası değil, ortak bir sorumluluk olduğunu öğrenmeleri beklenir. Benzer şekilde başarılı iletişim, bir araya getirilen ve kabul edilen grubun bir başarısıdır. Yaylı ve Yaylı’nın (2011: 18) belirttiği gibi öğrenen, öğrenme sürecine katkıda bulunur ve bağımsız bir yolla öğrenir. 


\subsection{1. Çoklu zekâ (multiple intelligences) uygulamaları ve öğretmen-öğrenci rolleri}

Gardner'ın (1999) “bilişsel profil” tanımlamasıyla açıklanan Çoklu Zekâ Kuramı’na göre, her birey en az 8 farklı zekâ türüne sahiptir ve her bireyde farklı zekâ türleri baskın olabilmektedir. Bu zekâ türleri Sözel/Dilsel, Mantıksal/Matematiksel, Görsel/Uzamsal, Ritmik/Müziksel, Bedensel/Kinestetik, Sosyal/Kişiler Arası Zekâ ve Doğa Zekâsı'dır. Çoklu zekâ üç alandan oluşmaktadır: Analitik, iç gözlemle ilgili ve etkileşimli alanlar. Bu üç alan, zekânın değişken ilişkisini ve zekâların birbirleriyle nasıl çalıştığını anlamak için bir düzenleyici görevi görmektedir. Öğretmenler, sınıftaki tüm zekâ türlerini etkili bir şekilde ele alan dersleri planlayabilirler (McKenzie, 2002). İdeal olarak herhangi bir sinıfta öğrenme, bütün öğrenenler için kişisel gelişim ve büyüme içerecektir. Bu nedenle, bugünün dil sınıfında sadece dilsel yetkinliği ve hatta iletişimsel yeterliliği desteklemek yeterli değildir (Arnold ve Fonseca, 2004: 130). Öğrenenlerin bireysel farklılıklarına da dikkat edilmelidir.

Çoklu Zekâ uygulamalarının kullanıldığı eğitim, daha çok öğrenen merkezlidir ve öğrenenlerin en yüksek potansiyele ulaşmasına yardımcı olmak için çeşitli öğretim etkinliklerini içermektedir (Haley, 2004). Çoklu Zekâ Teorisi, eğitimin kaynă̆ını kuran çok faydalı bir araç olabilir: Çeşitli zekâya ve düşünme biçimlerine hitap eden konuları, bireysel farklılıklara değinen öğretim yöntemlerini ve standartların ötesine geçen değerlendirmeleri de içerir (Chen, Moran ve Gardner, 2009: 14).

Campbell (1997: 19) Çoklu Zekâ teorisiyle ilgili şunları söylemektedir: Kuralcı değildir. Daha ziyade, öğretmenlere müfredat oluşturmak ve kendilerini eğitimciler hâline getirmek için karmaşık bir zihinsel model verir. Bu görüşte, öğretmenlerin Çoklu Zekâ modelini anlamaları, ustalaşmaları ve bunlarda kararlı davranmaları beklenir. Öğretmenlerin kendileri üzerinde bir Çoklu Zekâ envanteri oluşturmaları ve böylece "hayatın deneyimlerini Çoklu Zekâ" (Christison, 1997: 7) kavramına bağlamaları teşvik edilmektedir (Richards and Rodgers, 2002: 120). Öğretmenlerin kendilerini yalnızca dil öğretmeni olarak düşünmemeleri teşvik edilir. Öğretmenlerin sadece öğrencilerin ikinci dil yeteneklerini geliştirmek için değil, "öğrencilerin zekâlarının genel gelişimine katkıda bulunanlardan” (Christison, 1999: 12) olmaları gibi bir rolü vardır. Öğretmenler gibi, öğrencilerin de kendilerini başarılı bir dil öğreneni olmaktan çok ve gelişim süreci içinde olduklarını görmeleri gerekir. Çoklu Zekâ sınıfı, tüm öğrencilerin gelişimini desteklemek üzere tasarlanmıştır. Bu sınıfın etkinlikleri de öğrencilerin genel olarak daha iyi bireyler ve daha başarılı öğrenciler olabilmeleri içindir. Öğrencilerin genellikle bir Çoklu Zekâ envanteri almaları ve envantere dayanan kendi Çoklu Zekâ profillerini geliştirmeleri beklenir (Christison, 1997: 9).

\subsection{2. İçerik temelli/odaklı öğretim (content-based instruction) ve öğretmen-öğrenci rolleri}

1965 yllından sonra Kanada St. Lambert tarafından geliştirilen Fransızca dil daldırma eğitiminden etkilenilerek geliştirilen (Memiş ve Erdem, 2013: 315) İçerik Temelli Öğretim, dil öğretimiyle farklı bir içeriği birleştirmeyi esas almaktadır. İçerik Temelli Öğretim Yöntemi ile dil öğrenenler, hem dil öğrenmekte hem de bir konu hakkında bilgi almaktadırlar. Böylece bilgi alırkan dil becerilerinin de geliştirilmesi söz konusu olmaktadır (Brinton, Snow ve Wesche, 1989'dan aktaran Büyükikiz, 2013c; Yaprak, 2015).

Öğretmen hedef dil ve içerik ile ilgili olarak öğrenme hedefleri düzenlemelidir. Sonra, öğretmen içerik çalışmaları için gerekli olan dili yapılandırarak her ikisini de öğretmek için etkinlikler oluşturur (LarsenFreeman ve Anderson, 2011: 184). İçerik Temelli Öğretim, dil öğretmenlerinin tipik rollerinde bir 
değişiklik beklemektedir. Öğretmenler, daha detaylı bir şekilde, planlama ve sunumlarında bağlam ve anlaşlabilirliği korumakla yükümlüdürler; sınıfta kullanmak için otantik materyalleri seçmek ve uyarlamaktan sorumludurlar; öğrencileri ihtiyaç analizcileri hâline gelmelidir ve gerçek anlamda öğrenci merkezli sinıflar yaratmalıdırlar (Richards and Rodgers, 2002: 214). İçerik Temelli Öğretim’in bir amacı, öğrenenlern özerk bir hâle gelmesi, böylece kendi öğrenme süreçlerini anlamaları ve kendi öğrenmelerini baştan itibaren üstlenmeleridir (Stryker and Leaver 1993: 286'dan aktaran Richards and Rodgers, 2002: 213).

\subsection{Görev temelli yöntem (task-based method) ve öğretmen-öğrenci rolleri}

Görev Temelli Yöntem, gerçek yaşam merkezli öğretimi mantıksal olarak takip eden İletişimsel Yaklaşım ile yakından ilişkilidir. Hem Görev Temelli Yöntem'de hem de İletişimsel Yaklaşım'da, etkili bir dil öğrenimi için üç yönün hayatî önemi vardır (Ciubancan, 2013: 60):

- Öğrencinin anlamlı bir ortamda hedef dile düzenli olarak maruz kalması;

- İletişimsel durumlarda hedef dilin aktif kullanımı için sık sık fırsat;

- Dil öğrenimi için güçlü motivasyon.

Görev Temelli Yöntem, öğrencilerin mevcut ve gelecekteki gerçek dünyada iletişim ihtiyaçlarını karşılamak için öğrenenleri ihtiyaç olunanlarla donatmayı hedeflemektedir (Long, 2007: 129). Bu süreçte öğrenenler, ilgi alanlarına yönelik verilen pedagojik görevlerle, yaparak yaşayarak dili öğrenirler (Benson, 2016: 342). Bu süreçte görev, "öğrencilerin bir düşünce sürecinde verilen bilgilerle bir sonuca varmaları ve öğretmenlerin de bu süreci kontrol etmeleri, düzenlemeleri için gereken etkinlikleri göstermeleri” (Prabhu, 1987'den aktaran Memiş ve Erdem, 2013: 314) kabul edilir. Görev, öğrenenlerin hedef dilde, "istenilen sonuca ulaşmak için iletişime dayalı olarak gerçekleştirilen etkinliklerde sergilenmek üzere üstlenip hayata geçirilen rollerle kendini gösteren performans göstergeleri” (Göçer, 2017b: 320) olarak tanımlanabilir. Görevler dil ile ilgili, iletişimsel, sosyokültürel, süreç odaklı veya kültürel olabilir (Nunan, 2011).

Görev Temelli Yöntem, hedef dilin pratik ve işlevsel kullanımıyla ilgili anlamlı sınıf ödevleri aracılığıyla öğrenenlere konuşma, okuma, dinleme ve yazma becerilerini deneyimleme firsatı sunar. Yöntem, öğretim sürecinde öğrenenlere, sürekli olarak hedef dili uygulama imkânı sunduğu için öğrenenlerin iletişim becerilerini geliştiren günlük yaşam aktivitelerini tamamlayarak dil becerilerinin kullanılması konusunda öğrenenleri teşvik eder (Córdoba Zúñiga, 2016: 14). Öğrenenler, görevler sırasında okurlar, not alırlar, bir topluluğa konuşur ve hedef dili ana dili olarak konuşanları dinlerler (Yorulmaz, 2009: 27). Görevlerin aşamaları şöyle açıklanmaktadır (Memiş ve Erdem, 2013: 315):

"Görev öncesi işlemler, konuya giriş niteliğindedir. Sınıftaki öğrencilere işlenecek olan konu başlığı ve öğrencilere verilecek olan görevler tanıtılır. Bunlar yapılırken de konu başlı̆̆ı ile ilgili kelime ve kalıplar kullanılır. Görevi yaparken öğrencilerin kullanacağı kelimeler öğretilir. Görevin nasıl yapılacağı, ne kadar süreceği gibi açıllamalar yapılır. Görev döngüsü işlemleri, görevin öğrenciler tarafından gerçekleştirildiği aşamadır. Öğretmen bu bölümde yalnızca yönlendirici ve gözlemci konumundadır. Öğrenciler ikişer olacak şekilde eşleştirilirler ve görevlerini tamamlarlar. Görev tamamlandıktan sonra öğrenciler görevle ilgili raporlarını planlarlar. Daha sonra öğretmen sözel ve yazılı bir şekilde bitirilmiş olan görevlerin düzeltilmesinde yardımcı olur. Çiftler sınıfın önünde yaptıkları görevin sunumunu icra ederler. Böylelikle öğrencilerin birbirinden öğrenmesine firsat verilir. Dile odaklanma işlemleri, görev 
döngüsü esnasında kullanılan dilde ortaya çıan dilin belli başlı özelliklerinin incelendiği aşamadır. $\mathrm{Bu}$ bölümde görevin analizi yapılır. Dil inceleme ve dil uygulama etkinlikleriyle dile odaklanma bir beceri olarak kazandırılmaya çalışılır.”.

Öğretmenin rolü, öğrencilerin düzeylerine uygun olan ve öğrencilerin ihtiyaç ve kabiliyetleriyle aynı düzeyde olan ön ödev ve ardışı ödev aşamalarını oluşturmak için öğrencilerin ihtiyaçları üzerine temellenen görevleri seçmektir. Öğretmen, öğrencilerin başarısını da gözlemler ve gerektiğinde devreye girer (Larsen-Freeman ve Anderson, 2011: 202). Etkinliklerin öğrenenlerin düzeyine uygun, güncel ve güdüleyici nitelikte olması için öğretmene önemli sorumluluklar düşmektedir (Yorulmaz, 2009: 26). Dil eğitiminin görevleri merkeze almasının, öğrenenlere deneysel bir eğitim süreci sunması beklenir. Öğrenenler anlam oluşturmak için hedef dili kullanırlar ve bu da onları dil edinimi konusunda teşvik eder (Samuda ve Bygate, 2008). Öğrenenlerin rolü, bir görevi tamamlamak için kendi akranlarıyla iletişim kurmak (Larsen-Freeman ve Anderson, 2011: 202); mümkün olduğu kadar hedef dilde iletişim kurarak görevi belirtilen hedef doğrultusunda tamamlamaktır (Kırkgöz, 2015: 239). Öğrenenler, problemleri çözdükleri ve yaratıcılık gösterdikleri gerçek iletişimi sağlayan aktif sınıf egzersizlerini, keşfetmenin bir yolu olarak görürler (Córdoba Zúñiga, 2016: 14).

\subsection{Eklektik/seçmeci/seçmeli yöntem (eclectic method) ve öğretmen-öğrenci rolleri}

Geçmişten günümüze, dil öğretiminde birçok yöntem kullanılmıştır. Geliştirilmesi öncelenen dil becerisine göre, yöntemlerin farklı özellikleri bulunmaktadır. Dil öğretim amacı, hedef kitlenin özellikleri ve ihtiyaçları gibi sebepler, yöntemlerin farklı özelliklerini daha önemli bir hâle getirmekte, yöntemin dil öğretimi için seçilmesini güçlendirmektedir. Uysal'ın (2019: 26) belirttiği gibi “öğretmen yeterliliği, öğrenci hazır bulunuşluğu, ders kitabının ön plana çıardığı dil becerisi, öğrenci ihtiyacı, öğretmen ve öğrenci arasında bir aracı dilin bulunup bulunmaması" gibi farklı faktörler de dil öğretiminde hangi yöntemlerin seçileceğini etkilemektedir.

Geçmişten günümüze pek çok yöntem geliştirilmiş olmasına rağmen gerçek anlamda tek başına yeterli ve ideal bir yöntemin varlığından söz edilemeyeceği belirtilmektedir (Alver, 2019: 17). Eklektik Yöntem’e göre de tek ve kesin doğru bir yöntem olmadığı gibi dil öğretiminde tek bir yönteme bağlı kalmak da doğru değildir. Öğrenme ortamındaki değişkenlere göre farklı dil öğretim yöntemleri seçilmelidir. Memiş ve Erdem'in (2013: 307) belirttiği gibi bu yöntemin temel ilkesi, tek ve kesin bir yaklaşımı olan yöntem yerine, dil öğretimi konusunda genel prensipler olmasıdır. Bir başka deyişle, "İyi yöntem yoktur." anlayışı yerine, iyi yöntemin duruma göre değiştiği anlayışını yansıtmaktadır (Altun Demir, 2015: 13). Örneğin sözcük öğretiminde Doğrudan Yöntem'e, dil bilgisi kurallarının öğretiminde Bilişsel Yöntem'e, dinleme ve konuşma eğitiminde İletişimsel Yöntem'e ağırlık verilebilir (Barın, 2004: 27). Yabancı dil öğretiminde, öğrenenlerin özelliklerinin, dil öğrenme amaçlarının, öğretimin hedefinin bilinmesi, dil öğretiminde seçilecek yöntemin belirlenmesi için önemlidir (Çangal, 2012; Göçer, 2017a; Kurt, 2010; Sebüktekin, 1973).

Dil öğretiminde, farklı becerilerin öğretiminde farklı yaklaşımların ve yöntemlerin, dil becerilerinin geliştirilmesine uygun olan taraflarının kullanılmasının söz konusu olduğu bu yöntemde öğretmenin, yaklaşımları ve yöntemleri iyi biliyor olması gerekmektedir. Stern (1987'den kataran Gür ve Gür, 1995: 78), çoğu öğretmenin kendisini bu yaklaşımı uyguluyor olarak nitelendirdiğini ancak bunun belirli bir yaklaşıma bağlı kalmamak demek olmadığını; "çeşitli düşünce ekollerinden seçimler yaparak seçmeci bir yaklaşım göstermek ile, sorumsuzca davranışlara bahane hazırlamak arasında fark” olduğunu 
belirtmektedir. Memiş ve Erdem’in (2013: 308) belirttiği gibi bu yöntemde, öğrenenlerin motivasyonları önemsenir ve bu sebeple öğretmen derse başlamadan önce öğrenenlerle iletişim kurar.

\section{Dil öğretim yöntemlerinin olumlu ve olumsuz özellikleri}

\subsection{Dil bilgisi-çeviri yönteminin olumlu ve olumsuz özellikleri}

Geçmişte, Dil Bilgisi-Çeviri Yöntemi’nin kullanılmasının ve uzun ömürlü olmasının sebeplerinden biri klasik metinleri okuyup anlayabilen ve bir uzman olarak çeviri yapabilen kişileri yetiştirmeye, toplumsal bir ihtiyaç duyulmasıdır. Yöntemin, dil öğretiminde hâlâ kullanıyor olmasının sebepleri arasında ise dilin kurallarının ağırlıklı öğretilmesinin, öğrenenin dil kullanımını kolaylaştıracağı inancı; derslerde konuşma ve dinleme becerilerine yeterince yer verilmemesi; dil bilgisi kurallarının öğrenenlerin ana dilinde açıklanmasının öğretmen için öğretimi kolaylaştırması sayılabilir. Liu ve Shi’ye (2007: 70) göre ise bunun sebebi, dil bilgisi öğretimiyle iletişimsel yaklaşım arasında çatışmaya yol açacak herhangi bir durum olmaması ve doğrudan dil bilgisi öğretiminin öğrencilerin hedef dildeki yapılarla ilgili farkındalıklarını artırma konusunda, iletişimsel dil öğretimine katkıda bulunabileceği düşüncesidir. Üstelik, ana dili, bir referans olarak ele alındığında, ikinci dil öğretiminde meydana gelebilecek yanlış anlamaların önüne geçer. Ardından, ikinci dilin özellikleri üzerine düşünmek ve çeviriyi bir pratik etme yöntemi olarak ele almak, öğrencileri etkin bir problem çözme durumuna sokar. Son olarak yöntem, uygulama konusunda nispeten daha kolaydır ve öğretmen için daha az talepkâr bir yöntemdir. Bu yöntemin bu kadar popüler olmasının sebebi de muhtemelen budur. Dil Bilgisi-Çeviri Yöntemi’ne karşı yenilikçiler tarafından yıkıcı eleştiriler de yapılmaktadır. Kimileri bu yöntemi, öğrencileri uzun ve kullanışsız dil bilgisi ve kelime listelerini ezberlemeye yönlendirmesinden ve öğrencileri, ana dillerinin baskısından kurtaracak türde alıştırmaların kısıtlı olmasından dolayı; kimileri de bu yöntemin, öğrencilerin iletişimsel yetkinliklerine çok az derecede önem vermesinden dolayı eleştirmektedir (Liu ve Shi, 2007: 69). Li'ye (2012: 166) göre de yöntemin en temel zararı şüphesiz öğrenenleredir. Çünkü, öğrenenler burada pasif bir şekilde gösterileni yapan kişiler durumundadır. Hao (2017: 743), Dil BilgisiÇeviri Yöntemi’nin olumlu ve olumsuz yönlerini şe şekilde belirtmektedir:

\begin{tabular}{|c|c|}
\hline Olumlu yönler & Olumsuz yönler \\
\hline Okuma ve yazma geliştirilir. & Dinleme ve konuşma göz ardı edilir. \\
\hline $\begin{array}{l}\text { Dilde biçim (form) ve sözdizimi (syntax) üzerinde } \\
\text { durulur. }\end{array}$ & İşlev (fonksiyon) ve anlam göz ardı edilir. \\
\hline $\begin{array}{l}\text { Çok miktarda bilgi çıkarım (tümdengelim) yoluyla } \\
\text { verilir. }\end{array}$ & Öğretmen merkezlidir \\
\hline $\begin{array}{l}\text { Özellikle büyük sınıflarda kullanımı kolaydır. } \\
\text { Dersi verecek öğretmenle ilgili yüksek beklentiler } \\
\text { yoktur. }\end{array}$ & $\begin{array}{l}\text { Öğgrenciler pasif durumdadır ve kolayca sıkılabilirler. } \\
\text { Öğretmen ile öğrenci arasında bir etkileşime önem } \\
\text { verilmez. }\end{array}$ \\
\hline $\begin{array}{l}\text { Dille ilgili temel bilgileri öğrenip bu konuda } \\
\text { uzmanlaşma konusunda faydalıdır. }\end{array}$ & Fazla miktarda bilgiyi ezberlemek zordur. \\
\hline
\end{tabular}

Bu yöntem, sınıf içi etkinliklerin düzenlenmesinin zor olduğu büyük sınıflarda kullanmak için uygundur. Ayrıca, hedef dilde yüksek bir yeterlilik seviyesi (özellikle konuşma becerisi açısından) olmayan öğretmenler tarafından da kullanılabilir. Dil bilgisi kurallarının bazı yanları ya da zorlayıcı metinleri açıklamak için kullanılabilir ama öğretim sürecinin tamamında kullanılmamalıdır (Hao, 2017: 743). 


\subsection{Doğrudan yöntemin olumlu ve olumsuz özellikleri}

Doğrudan Yöntem, konuşma ve iletişim becerilerine önem vermesiyle öğrenenlerin yabancı bir dili, etkili bir şekilde öğrenmelerine yardımcı olmaktadır. Bu süreçte, sözcüklerin öğretiminde farklı tekniklerin ve yeni materyallerin kullanılması yöntemin olumlu özelliklerinden biridir.

Doğrudan Yöntem şu iki noktanın sorgulanmasını kaçınılmaz hâle getirmiştir: Ana diline başvurmadan ve çeviri yapmadan yanlış anlamaların (özellikle bazı soyut kavramlar konusunda) önüne nasıl geçilecek; bu yöntem dil öğreniminde temel seviyenin ötesinde nasıl uygulanacak? Bunlara ek olarak, bu yöntem hedef dilin ana dili konuşucusu olan ya da hedef dilde ana dili konuşucusuna yakın seviyede akıcılığı olan öğretmenler gerektirir (Liu ve Shi, 2007: 70). Öğretmen merkezli olması ve öğretmenin sözü edilen dil kullanım özelliklerine sahip olma gerekliliği bu yöntemin en büyük dezavantajıdır (Memiş ve Erdem, 2013; Yaylı ve Yayll, 2011). Bununla beraber, öğrenenleri konuşturmaya yönelik olduğu için öğretmenlerin daha yetkin olması; dilin bağlam içerisinde öğretilmesi de söz konusu olduğundan, örnek durumlar için öğretmenin daha çok hazırlık yapması; öğretim için materyallerden fazlasıyla yararlanılması gibi öğretmen gerekleri Li’nin (2012: 166) belirttiği gibi, öğretmenler açısından çok şey gerektirdiğinden yöntem iddia edildiği kadar gerçekçi (uygulanabilir) değildir.

Yöntemde, okuma ve yazma becerileri göz ardı edilmektedir. Ayrıca Memiş ve Erdem’in (2013: 302) belirttiği gibi öğrenenler, hedef dilin dil bilgisi kurallarını yeterli düzeyde öğrenmeden kısa sürede konuşma becerisi kazandıklarından, öğrendikleri sözcükleri kendi ana dili mantığına uygun olarak kullanırlar ve bu, dilbilgisel ve anlamsal problemler yaşamasına neden olur.

\section{3. İşitsel-dilsel yöntemin olumlu ve olumsuz özellikleri}

İşitsel-Dilsel Yöntem’in, yabancı dil öğretim tarihindeki en popüler yöntemlerden biri olarak, dil öğretimine çok büyük katkıları olmuştur. Örneğin, dil öğretiminin o dili öğrenmek için soyut kavramlar konusunda yüksek kabiliyet gerektirmeyecek şekilde düzenlenmesi gerektiğini savunarak dil öğretimini, sıradan öğrenenlerden oluşan büyük gruplar için de erişilebilir hâle getirmiştir. Buna ek olarak, kendisinden önce ortaya çlkmış olan yöntemler, sözcük ve biçim bilgisine yoğunlaşırken bu yöntem sözdizimsel (syntax konusunda) ilerlemeye önem vermiştir (Liu ve Shi, 2007: 70).

İşitsel-Dilsel Yöntem'de dinleme ve konuşma becerilerine daha fazla önem verilmektedir. Abu-Melhim'e (2009: 43) göre bunun arkasında yatan teori, iyi bir dinleyici olanların okuma ve yazma açısından da iyi olacakları yönündeki düşüncedir. Bundan dolayı, asıl önem dinleme ve konuşma becerilerine verilir. $\mathrm{Bu}$ da İşitsel-Dilsel Yöntem’in başka bir avantajını ortaya çıkarır. Öğretmenler, tonlamaya ayrıca dikkat ederek doğru telaffuzun önemini vurgular.

Yöntem, dilin yapısal özellikleri ve kalıp ifadeler üzerinde durduğundan dil kullanımında hatalar aza indirilmiştir. Uzun ve klasik okuma metinlerinin aksine öğrenenlerin ilgilerine yönelik diyaloglarla çalışılması öğrenenler için daha eğlencelidir.

İşitsel Dilsel Yöntem’in bir başka avantajı da hedef dili konuşanların kültürel art alan bilgilerine önem verilmesidir. Dili oluşturan kültürün anlaşılmasıyla öğrenenler, özellikle dil ve kültürün birbiri üzerinde büyük etkisi olmasından dolayı, ufak anlam farklılıklarına aşina olurlar (Abu-Melhim, 2009: 43).

Bütün bu katkılarına rağmen İşitsel-Dilsel Yöntem birçok yönüyle eleştirilmiştir. İlk olarak, teorik temeline yönelik hem dil teorisi hem de öğrenme teorisi açısından kusurlu olduğu gerekçesiyle 
Chomsky'in Dönüşümsel Dil Bilgisi Teorisi (Transformational Grammar) tarafindan eleştiriler yöneltilmiştir (Liu ve Shi, 2007: 70). Bir başka eleştiri, yöntemin iletişim ile bağlantısına yapılmıştır. Dilin yapısal özelliklerinin ve kalıp ifadelerinin ezberlenmesi ve pratik edilmesiyle dilin akıcı ve yetkin bir şekilde konuşulacağı düşünülse de öğrenme çıtıları incelendiğinde, sonuç umulduğu gibi olmamıştır. Yıllar sonra görülmüştür ki öğrenenler, ezberledikleri diyalogları hâlâ hatırlamakta ancak dili konuşamamaktadırlar. Yöntem "gerçek" iletişim içinde başarılı olamamış, iletişimde bir firsat sağlamamıştır. Yöntem sınıf ortamında, bir senaryo gibi kalmış; öğrenenlerin gerçek hayatta konuşabilmelerini tam olarak sağlayamamıştır. Brown'un (2007: 112) belirttiği gibi yöntem, uzun vadede iletişimsel becerileri geliştirmede yetersiz kalmıştır; sonradan anlaşılmıştır ki dil öğrenimi alışkanlık oluşturma yoluyla gerçekleşmez ve hatalardan tamamen arınmış bir sürece gerek yoktur. Yöntemin uzun vadede iletişimsel becerileri geliştirmede yetersiz olma sebeplerinden biri de AbuMelhim'e (2009: 43) göre, belki de en önemlisi, öğrenenlerin yöntemin sıkıcı ve uğraştırıcı olduğunu düşünmesidir. Öğrenenlerin ilgisini çekmez ve ders başladıktan kısa bir süre sonra öğrenenler, alıştırmaları mekanik ve yavan bulurlar. Bu yöntem, çocuklar için daha ilgi çekici olabilecekken, yetişkin öğrenenler genellikle ilgisizdir. Bu sebeple öğrenilenleri uzun vadede hatırlama oranları düşüktür.

Öğrenenler belirli yapılar üzerinden dili kullandıkları için yaratıcılıklarının da göz ardı edildiği söylenebilir. Oysa dil bir alışkanlıktan öte, dil kurallarına uygun olarak yeni kurallar üretmeyi içermektedir. Hao (2017: 743), İşitsel-Dilsel Yöntem'in olumlu ve olumsuz yönlerini şu şekilde belirtmektedir:

\begin{tabular}{ll}
\hline Olumlu yönler & Olumsuz yönler \\
\hline $\begin{array}{l}\text { Öğrencilerin cümle ve dil bilgisel yapı üretme becerileri } \\
\text { iyi bir şekilde geliştirilebilir. }\end{array}$ & $\begin{array}{l}\text { Çok sayıdaki mekanik alıştırmalar sıkıcı olabilir. } \\
\text { Eğitim mekanik bir şekilde gerçekleştirilir. }\end{array}$ \\
\hline Sözlü beceriler daha iyi bir şekilde geliştirilebilir. & Okuma becerileri biraz zayıf kalabilir. \\
\hline Sözdizim ve yapıya önem verilir. & İşlev (foksiyon) ve anlam göz ardı edilir. \\
\hline $\begin{array}{l}\text { Kısmen öğrenci merkezlidir. } \\
\text { Öğrenciler pratik yapma açısından daha aktiftir. }\end{array}$ & $\begin{array}{l}\text { Öğrencilerin pratik yapmalarını sağlayacak sınıf içi } \\
\text { etkinlikler yeterli ve etkili değildir. }\end{array}$ \\
$\begin{array}{l}\text { Öğretmenlerle öğrenciler arasında daha çok etkileşim } \\
\text { söz konusudur. }\end{array}$ & $\begin{array}{l}\text { Telaffuz, kelime, dil bilgisi, metin vs. gibi farklı öğretim } \\
\text { hedefleri için farklı farklı etkinlikler düzenlenmelidir. }\end{array}$ \\
\hline
\end{tabular}

Bu yöntemin, İşbirlikli Öğrenme ve Görev Temelli Öğrenme gibi etkili yöntemlerle birleştirilerek kullanılması daha iyi olacaktır (Hao, 2017: 743).

\subsection{Sessiz yol yönteminin olumlu ve olumsuz özellikleri}

Sessiz Yol, öğrenen özerkliğini ve öğrenen merkezli öğretim kavramını tanıtan ilk yöntemlerdendir. Sessiz Yol, öğretmenin yöntemi kullanması için kapsamlı eğitim almasını gerektiren oldukça karmaşı bir yöntemdir. Ayrıca öğrencilerin de derslere etkili bir şekilde katılmak için çizelgelerin ve çubukların kullanımı konusunda iyi bir yeteneğe sahip olmaları gerekir.

Öğrenenler, kendi kendilerine nasıl öğrenebileceklerini öğrensinler diye bağımsızlık, otonomi ve sorumluluk kazanırlar. Ancak hiç dönüt verilmemesi, istenilen sonuçlar doğuracağı anlamına gelmez. İçerik, iletişimsel değer açısından eksiktir (Li, 2012: 167). Bu yöntemin en çok eleştirilen noktası da öğrenenlerin gerçek dil materyali ve ortamı ile karşılaşmadıkları için öğrenenlerin, dili iletişim aracı olarak kullanmalarının zor olmasıdır. Ayrıca yöntemin bir diğer eleştirilen yanı da konuşma becerisini ihmal etmesidir (Memiş ve Erdem, 2013: 312). 


\subsection{Grupla/danışmanlı dil öğretim yönteminin olumlu ve olumsuz özellikleri}

$\mathrm{Bu}$ yöntemde, öğretmen çalışma grubunun dışında kalır ve öğrenenlere danışmanlık yapar. Bu da öğrenenlerin dil öğretiminde karşılaştıkları kaygı, stres ve yanlış yapma korkularını yenmelerine yardımcı olur. Öğretim süreci, öğrenenlerin ilgi ve ihtiyaçlarına göre düzenlendiğinden öğrenenlerin ilgi ve motivasyonları artar. Ayrıca öğrenenler, ders sürecinde grup olarak bir konu üzerinde konuştuklarından hedef dil iletişimsel olarak ve kültürel olarak öğrenilir (Bölükbaş, 2013b: 70).

Öğretmenlerin hedef dili, hedef dilin dil bilgisi kurallarını, danışmanlık için psikolojiyi bilmeleri gerekir. Yöntemin kalabalık sınıflarda uygulanması zordur. Uygulama sürecinde öğretimin, öğrenenlere göre düzenlenmesi, ders programının izlenmesini zorlaştırır. Öğrenenleri değerlendirme aşamasında sorunlar yaşanabilir. Dil bilgisi öğretimi açısından da yöntemin eksiği vardır (Bölükbaş, 2013b: 71; Erdem, Gün ve Sever, 2015: 562; Memiş ve Erdem, 2013: 311). Yöntemin bir başka olumsuz yönünü ise Bölükbaş (2013b: 71) şöyle açıklamaktadır: "Yöntem, öğrencilerin ana dillerinde konuşup bunların hedef dile aktarılmasına dayalı olduğundan, sadece öğrencilerin aynı ana dili konuştuğu gruplarda uygulanabilir. Bu nedenle, Türkiye'de verilecek yabancı dil olarak Türkçe derslerinde, öğrenciler farklı ülkelerden geldikleri ve dolayısıyla da ana dilleri farklı olduklarından bu yöntemin kullanılması mümkün değildir.”.

\section{6. İşbirlikli öğrenme yönteminin olumlu ve olumsuz özellikleri}

İşbirlikli Öğrenme Yöntemi’nin sağladığı yararlar şunlardır: Benlik saygısının kazanılması, okulun sevilmesi, etnik gruplar arası ilişki kurulması, artan öğrenci konuşması, daha çeşitli konuşma, daha rahat bir atmosfer, daha fazla motivasyon, daha fazla anlam üzerinde uzlaşma ve anlaşılabilir girdinin artan miktarı (Johnson, Johnson ve Holubec, 1993; Liang, Mohan ve Early, 1998; Olsen ve Kagan, 1992; Slavin, 1995). Bu yöntemin olumsuz özelliği olarak ise, grup çalışması gerektirdiğinden kalabalık sinıflarda uygulanmasının zor olması söylenebilir.

\subsection{Telkin yöntemi/esinlemeli yöntemin olumlu ve olumsuz özellikleri}

Bu yöntem ile yabancı dil öğretim tarihinde müzik, oyun gibi öğretim teknikleri geleneksel öğretim yöntemleriyle karşılaştırıldığında resmen tanınmaya başlanmıştır. Yöntemin temeli, insanların yabancı dil öğretim sürecinde yaşadığı başarısızlık korkusunun öğrenmeyi etkilediğidir. Rahatlatıcı sınıf ortamı, müzik ve gevşeme egzersizleri yoluyla beynin öğrenme potansiyeli de artacak ve böylece geleneksel yöntemlere kıyasla en az üç kez yabancı dil öğretim sürecini kısaltacaktır. Yöntem bu açıdan eğlenceli bir sınıf ortamı ve başarılı bir öğretim süreci sağlar görünmektedir. Ancak Akpınar Dellal ve Akbay Pişkin'e (2015: 43) göre okuma ve yazma etkinliklerine daha fazla ağırlık verilmesi yöntemi daha kullanışlı bir hâle getirecektir.

Telkin Yöntemi, kalabalık olmayan sınıflar için ideal olan bir dil öğretim yöntemi (İşcan, 2011: 1320) olsa da yöntemin uygulanması büyük sınıflar için pratik değildir. Buna ek olarak, mevcut ders kitapları bu metodolojiyi benimsemediğinden öğretmenlerin bu ilkeleri normal sınıflarda uygulamaları da zor görünmektedir.

\subsection{Tüm (toplu) fiziksel tepki yönteminin olumlu ve olumsuz özellikleri}

Tüm Fiziksel Tepki Yöntemi, dil gelişiminin ön hazırlık/sessizlik aşamasında, başlangıç seviyesinde olan öğrencilerle çalışmak için etkili bir yöntemdir. Henüz dili konuşma aşamasında olmayan öğrenciler, 
derslere dâhil olabilir ve sözsüz olarak tepki verebilirler. Böylece, öğrenenler başarı hissini hissedebilirler.

Yöntem, sınıfta aktif olması gereken kinestetik/bedensel zekâsı yüksek olan öğrenciler için uygundur. Kalabalık ya da küçük sınıfların ikisinde de kullanılabilir. Öğretmen sınıfa rehberlik ettiği sürece öğrenciler kendisini takip edecektir. Fiziksel aktiviteler, tüm öğrenenlerin hedef dili anlamaları ve uygulamaları için anlamı etkili bir şekilde anlaşılır kılar. Bu yöntemde, öğretmen yapmak istediği konusunda yetkin olduğu ve önceden pratik yaptığı sürece çok fazla hazırlığa ya da materyal kullanımına gerek yoktur. Gençler ve genç öğrenenler için etkili bir yöntemdir ve hem sol hem să̆ beyinli öğrenmeyi içerir.

Young’tan (2000: 239) hareketle yöntemin dezavantajları şöyle özetlenebilir: Bu yönteme alışık olmayan öğrenciler, yöntemin kullanıldığı durumlarda utanabilirler. Öğretmen, eylemleri kendisi gösterirse öğrenciler, eylemleri yerine getirme konusunda daha mutlu hissedebilirler. Yöntem, orta ve ileri seviyelerde de uygulanabilir olmasına rağmen gerçek anlamda başlangıç seviyesinde öğrenenler için kullanılmaya uygundur. Bu yöntem, diğer yöntem ve tekniklerle birlikte kullanıldığında, bir dersin dinamiklerini ve hızını değiştirmenin eğlenceli bir yolu olabilir. Yöntemin uygulanmasında bedensel bir enerji ihtiyacı olduğundan, yöntem başka yöntemlerle birleştirilmelidir; böylece öğrenenler dili öğrenmekten yorulmazlar.

\subsection{Görsel-işitsel yöntemin olumlu ve olumsuz özellikleri}

Yöntemin teknolojiyi dil öğretimine katmış olması dil pedagojisine taze bir alternatif getirmiştir (Stern, 1987'den aktaran Gür ve Gür, 1995: 74). Öğrenenler, teknolojinin kullanılması yoluyla görerek ve duyarak daha kalıcı olarak öğrenebilirler.

Yöntemin olumsuz yönlerinden biri olarak öğretilmesi hedeflenen anlam ile gösterilen görsel arasındaki ilişkinin yanlış yorumlanabileceği söylenebilir. Memiş ve Erdem'e (2013: 314) göre de yöntemin başlıca öğretim tekniklerinden olan tekrar, derslerin bir süre sonra sıkıcı hâle gelmesine neden olabilmektedir.

\subsection{0. İletişimsel dil öğretim yönteminin olumlu ve olumsuz özellikleri}

İletişimsel Dil Öğretim Yöntemi’nin dil öğretimine getirdiği yenilik, öğrenenlerin iletişim kurma becerisini kazanmalarıdır. Ancak yöntem, yabancı dilde iletişimi temel aldığından ve hatalı bir konuşma da olsa iletişim kurabilmeye önem vermesinden, öğrenenlerin dil bilgisini yanlış kullandıklarına yönelik eleştiriler almaktadır. Hao (2017: 744), İletişimsel Dil Öğretim Yöntemi’nin olumlu ve olumsuz yönlerini şu şekilde belirtmektedir:

\begin{tabular}{ll}
\hline Olumlu yönler & Olumsuz yönler \\
\hline Öğrencilerin iletişimsel yeterliliği geliştirilebilir. & $\begin{array}{l}\text { Öğretmenlerin hedef dilde yeterlilik ve öğretim } \\
\text { teknikleri için yüksek bir gereksinimi vardır. }\end{array}$ \\
\hline Sözlü yetenek daha iyi geliş̧irilebilir. & $\begin{array}{l}\text { Öğrencilerin sistemik dil bilgisinde zayıf olmaları } \\
\text { mümkündür. }\end{array}$ \\
\hline İşlev ve anlam vurgulanır. & Söz dizimi ve biçim daha az vurgulanır. \\
\hline $\begin{array}{l}\text { Öğrenci merkezlidir. } \\
\begin{array}{l}\text { Öğrenciler aktif olarak etkinliklere katılmaktan motive } \\
\text { olurlar. Öğretmenler ve öğrenciler arasnda ve } \\
\text { öğrencilerin kendi aralarında daha fazla etkileşim var. }\end{array}\end{array}$ & Doğrencilerin hataları zaman içinde düzeltilemez. \\
\hline
\end{tabular}


Bu yöntemi, daha iyi iletişim becerilerine sahip olmaları için ilköğretim öğrencilerine öğretmek daha uygundur. Yöntem, sözlü öğretimde de etkili bir şekilde kullanılabilir. Yöntemi, İşitsel-Dilsel Yöntem ile birlikte kullanmak daha iyidir (Hao, 2017: 744).

İletişimsel Dil Öğretimi, yetişkinler ve güçlü çalışma güdüsü olan öğrenenler için tasarlanmıştır. Böyle bir öğretim yöntemi, çocuklara ya da yabancı dil eğitim durumu zayıf olan okullara tam olarak uymamaktadır (Shuang ve Xin, 2011: 1071).

\subsection{1. Çoklu zekâ uygulamalarının olumlu ve olumsuz özellikleri}

Öğrenenlerin farklı ihtiyaç ve ilgilerine göre tasarlanan dersler, öğretim sürecini sıkıcı olmaktan kurtarmaktadır. Öğrenenlerin öğrenmeleri, farklı zekâ türlerine hitap eden etkinlikler aracılığıyla daha iyi gerçekleşebilir. Etkinlikler, farklı zekâ türlerine göre tasarlansa da ölçme-değerlendirme etkinlikleri öğrenenlerin farklı zekâ türlerine göre yapılamamaktadır.

\subsection{2. İçerik temelli/odaklı öğretim yönteminin olumlu ve olumsuz özellikleri}

Dil öğretimine içeriğin dâhil edilmesi bu yöntem ile olmuştur. Memiş ve Erdem’in (2013: 316) belirttiği gibi İçerik Temelli Öğretim Yöntemi’nin dayandığı yaklaşımın net olmayışı; henüz sistemleşmemiş olması; özgünlükten çok diğer yöntemlerin ihmal ettiği içeriğe odaklanması ama yeni bir özelliğinin olmaması; dünyanın her yerinde aynı sistematik ile uygulanan bir yöntem olmayışı eleştirilen yönleridir.

\subsection{Görev temelli yöntemin olumlu ve olumsuz özellikleri}

Görev Temelli Yöntem, dil öğretimine, iletişim temelli görevleri getirerek bir yenilik yapmıştır. Böylece iletişimsel dil becerilerini kazanabilmeleri için öğrenenlere firsatlar sunmak söz konusu olmuştur.

Görev Temelli Yöntem, etkili bir pedagoji olarak giderek daha fazla kabul görmüştür ancak genelleştirilmiş sosyokültürel öğrenme kuramlarındaki yeri, yanlış anlaşılmalara ve eleştirilere yol açmıştır. Görevlerin kontrol yapısının yokluğunun öngörülemeyen sonuçlara yol açabileceği ve yöntemin sadece yüksek hedef dil yeterliliğine sahip tecrübeli öğretmenler için uygun hâle getirildiği iddia edilmektedir. Sınav hazırlı̆̆ı için uygun görülmemektedir ve iddiaya göre dil bilgisi kurallarının öğrenilmesi için yeterince ayrıcalıklı değildir (Willis ve Willis, 2012). Ayrıca başlangıç seviyesi öğrencileri için de uygun görülmemektedir (Erdem, Gün ve Sever, 2015: 563). Hao (2017: 744), Görev Temelli Yöntem’in olumlu ve olumsuz yönlerini şu şekilde belirtmektedir:

\begin{tabular}{|c|c|}
\hline Olumlu yönler & Olumsuz yönler \\
\hline $\begin{array}{l}\text { Öğrenciler problemleri çözmek için öğrenmeye çok } \\
\text { motive olurlar. }\end{array}$ & $\begin{array}{l}\text { Öğretmenlerin hedef dil yeterliliği ve öğretim } \\
\text { teknikleri için çok yüksek bir beceriye gereksinim } \\
\text { vardır. }\end{array}$ \\
\hline $\begin{array}{l}\text { Dinleme ve konuşma, okuma ve yazma becerisinden } \\
\text { önce gelen giriş etkinlikleridir. }\end{array}$ & $\begin{array}{l}\text { Öğrencilerin sistemik dilbilgisinde zayı olması } \\
\text { mümkündür. }\end{array}$ \\
\hline İşlev ve anlam vurgulanır. & Sözdizimi ve biçim sınırlı zamanda kullanılır. \\
\hline $\begin{array}{l}\text { Öğrenen merkezlidir. } \\
\text { Öğretmenler danıșmanlardır. }\end{array}$ & $\begin{array}{l}\text { Görev etkinliklerini organize etmek ve öğrenenleri } \\
\text { özellikle büyük smıflarda yönetmek zordur. }\end{array}$ \\
\hline $\begin{array}{l}\text { Öğrencilerin, gerçek yaşam durumlarına benzer } \\
\text { görevleri, hedef dili kullanarak bitirmeleri } \\
\text { gerekmektedir. }\end{array}$ & $\begin{array}{l}\text { İlgili değerlendirme sisteminin } \\
\text { konusudur. }\end{array}$ \\
\hline
\end{tabular}


$\mathrm{Bu}$ yöntem, iyi bir yöntemdir ve ilkokul, ortaokul ve hatta kolej öğretiminde kullanılması uygundur. Ancak iki şeye sahip olunmalıdır: Öğretmenlerin yüksek hedef dil yeterliliği ve etkili öğretim teknikleri (Hao, 2017: 744).

\subsection{Eklektik/seçmeci/seçmeli yöntemin olumlu ve olumsuz özellikleri}

Eklektik Yöntem’i kullanmak, tek bir dil öğretim yönteminin sınırları içinde kalmamaya yardımcı olmaktadır. Yöntem, farklı yöntemlerin ihtiyaç ve hedefe uyan uygun özelliklerinin alınmasına fırsat vermekte, birden çok yöntemin aynı anda kullanılmasını sağlamaktadır. Böylece, bir sınıf ortamında öğretim süreciyle ilişkili olarak öğrenenler için en uygun dil öğretim yöntemi kullanılmış olmakta, öğrenenlerin en iyi şekilde öğrenmelerine firsat verilmiş olmaktadır. Gür ve Gür’e (1995: 79) göre, yöntem dil öğrenenlerin özelliklerinin önemini vurgulaması bakımından önemlidir.

Eklektik Yöntem’in olumsuz özelliklerinden biri, öğretim sürecinde seçilecek yöntemlerin hangi kurallara dayanılarak seçileceği konusunda bir öneri getirmemesidir (Stern, 1987'den aktaran Gür ve Gür, 1995: 79). Bu yöntem, farklı yöntemlerin seçimini gerektirdiğinden, bu yöntemi kullanacak olan öğretmenlerin iyi ve kötü arasında bir tercih yapabilmesi için geniş bir bilgi birikimine sahip olması gerekmektedir. Bu yetenekleri taşıyan bir öğretmen bulmak da bu yöntemin bir diğer olumsuz özelliğidir. Öğretmenlerin yöntem seçimlerini bireysel olarak yapmaları ise birden fazla öğretmenin çalıştığı bir kurumda karışıklığa neden olabilmektedir (Memiş ve Erdem, 2013: 308).

\section{Sonuç}

Dil öğretiminin tarihi boyunca, dil öğretim yöntemlerinde değişimler yaşanmıştır. Dilin daha iyi öğretilebilmesi adına daha iyi yollar bulunması için araştırmalar yapılmıştır. Araştırmalar ile ortaya konan özellikler, dil öğretim yöntemlerindeki öğretmen-öğrenci rollerinin özelliğini de belirlemiştir. Daha iyi bir öğretimin olabilmesi için öğretmenlerin ve öğrencilerin dil öğretim sürecindeki rollerinde değişimler yaşanmıştır. Dil öğretiminde var olan her bir yöntem, dil öğretiminin etkililiğini hedeflediğinden, dil öğretimine olumlu özellikler sunmaya çalışmıştır. Bununla beraber, dil öğretim yöntemlerinin öğretim sürecinde kullanılması yoluyla yöntemlerin eksikliklerinin de farkına varılmış ve bunlar da yöntemlerin olumsuz özellikleri olarak belirlenmiştir.

Günümüzde, dilin sosyal bir etkileşim aracı olduğu görüşünden hareketle, dil öğretiminde öğrenenleri zengin bir dil girdisine maruz bırakarak, öğrenme ortamlarını görsel, işitsel araçlarla destekleyerek öğrenenlerin gerçek iletişim ortamlarında dili bağımsız bir şekilde öğrenmelerini sağlamak önemlidir (Aktaş, 2005; Arslan ve Adem, 2010; Güneş, 2013a; Işık, 2008). Bugün, dil öğretim sürecinde tek bir öğretim yöntemine bağlı kalmak, öğrenenlerin dil becerilerini geliştirmek ve dili öğretmek bakımından yetersiz kalmaktadır. Dil öğretimine farklı yöntemleri dâhil edebilmek içinse yöntemleri tanımak, yöntemlerdeki öğretmen-öğrenci rollerini bilmek ve yöntemlerin olumlu ve olumsuz özelliklerinin farkında olmak gerekmektedir. Türkçenin yabancı dil olarak öğretiminde de Türkçe öğrenenlerin dili en kolay ve etkili bir şekilde öğrenebilmeleri için yöntem bilgisine sahip olmak bir dil öğretmeni için önemli bir ihtiyaçtır. Bu bağlamda, Türkçeyi yabancı dil olarak öğretenlerin yöntemler konusunda kendini geliştirmeleri ve öğrenenlere en uygun dil öğretim ortamını yaratmaları beklenmektedir. 


\section{Kaynakça}

Abu-Melhim, A. (2009). Re-evaluating the effectiveness of the audio-lingual method in teaching English to speakers of other languages. International Forum of Teaching and Studies, 5(2), 39-45.

Akpınar Dellal, N., \& Akbay Pişkin, M. (2015). Yabancı dil öğreten eğitimcilerin telkin yöntemine ilişkin algı ve görüssleri. Turkish Studies - International Periodical for the Languages, Literature and History of Turkish or Turkic, 10(3), 37-50.

Aktaş, T. (2005). Yabancı dil öğretiminde iletişimsel yeti. Journal of Language and Linguistic Studies $12,89-100$.

Altun Demir, N. (2015). Yöntem sonrası pedagoji: Yöntemlerin özgünlüğü, uygulanabilirliği, olabilirliği. Eğitim Bilim Toplum Dergisi, 13(50), 9-23.

Alver, M. (2019). Türkçenin yabancı dil olarak öğretiminde esas alınan ilkeler ile kullanılan yöntem ve teknikler. İ. Erdem, B. Doğan ve H. Altunkaya (Ed.), Türkçenin Yabancı Dil Olarak Öğretimi (1342). Ankara: Pegem Akademi.

Arnold, J., \& Fonseca, C. (2004). Multiple intelligence theory and foreign language learning: A brainbased perspective. International Journal of English Studies, 4(1), 119-136.

Aykaç, N. (2015). Yabancı dil olarak türkçe öğretiminin genel tarihçesi ve bu alanda kullanılan yöntemler. Turkish StudiesInternational Periodical For The Languages, Literature and History of Turkish or Turkic, 1O(3), 161-173.

Barın, E. (2004). Yabancılara türkçe öğretiminde ilkeler. Türkiyat Araşttrmaları(1), 19-30.

Batdı, V. (2013). İşbirlikli öğrenmenin yabancı dil öğretimindeki önemine ilişkin öğretmen görüşleri. Eğitim ve Öğretim Araştırmaları Dergisi, 2(1), 158-165.

Bekleyen, N. (2015). Dil öğretiminin tarihsel gelişimi. N. Bekleyen (Ed.), Dil Öğretimi (s. 3-21). Ankara: Pegem Yayınları.

Benson, S. D. (2016). Task-based language teaching: An empirical study of task transfer. Language Teaching Research, 20(3), 341-365.

Bölükbaş, F. (2013a). İşitsel-dilsel yöntem (Audio-lingual method). M. Durmuş, \& A. Okur (Ed.), Yabancılara Türkçe Öğretimi El Kitabı (s. 61-65). İstanbul: Grafiker Yayınları.

Bölükbaş, F. (2013b). Grupla dil öğretim yöntemi (Community language learning). M. Durmuş, \& A. Okur (Ed.), Yabancılara Türkçe Öğretimi El Kitabı (s. 67-71). Ankara: Grafiker Yayınları.

Bölükbaş, F. (2013c). Dil öğretiminde işbirlikli öğrenme (Cooperative learning). M. Durmuş, \& A. Okur (Ed.), Yabancılara Türkçe Öğretimi El Kitabı (s. 73-78). Ankara: Grafiker Yayınları.

Brinton, D., Snow, M., \& Wesche, M. (1989). Content-based second language instruction. New York: Newbury House.

Brown, H. D. (2007). Principles of language learning and teaching. White Plains, NY: Pearson, Longman.

Büyükikiz, K. K. (2013a). Doğal yaklaşım (Natural approach). M. Durmuş, \& A. Okur (Ed.), Yabancılara Türkçe Öğretimi El Kitabı (s. 87-89). Ankara: Grafiker Yayınları.

Büyükikiz, K. K. (2013c). İçerik odaklı öğretim (Content-based instruction). M. Durmuş, \& A. Okur (Ed.), Yabancılara Türkçe Öğretimi El Kitabı (s. 125-128). Ankara: Grafiker Yayınları.

Calp, M. (2017). Yabancılara Türkçe öğretiminde alternatif bir yöntem: İşitsel-dilsel yöntem. International Journal of Languages' Education and Teaching, 5(4), 611-633.

Celce-Murcia, M. (1991). Language and communication: A time for equilibrium and integration. J. E. Alatis içinde, Georgetown University round table on language and linguistics (s. 223-237). Washington, DC: Georgetown University Press.

Celce-Murcia, M. (2001). Teaching English as a second or foreign language. Boston, Massachusetts: Heinle \& Heinle Publishers. 
Chen, J. Q., Moran, S., \& Gardner, H. (2009). Multiple intelligences theory around the World. San Francisco, CA: Jossey-Bass Publishers.

Ciubancan, M. (2013). From task-supported teaching to task-based learning. Euromentor Journal, 4(1), $56-65$.

Córdoba Zúñiga, E. (2016). Implementing task-based language teaching to integrate language skills in an efl program at a Colombian university. Profile Issues in Teachers' Professional Development, 18(2), $13-27$.

Çangal, Ö. (2012). Yabancılara Türkçe öğretiminde kültür taşıyıcısı olarak türküler. Gazi Üniversitesi Türkçe Araştırmaları Akademik Öğrenci Dergisi, 2(2), 9-20.

Demir, A., \& Açık, F. (2011). Türkçenin yabancı dil olarak öğretiminde kültürlerarası yaklaşım ve seçilecek metinlerde bulunması gereken özellikler. TÜBAR, XXX, 51-72.

Demircan, Ö. (2013). Yabancıdil öğretim yöntemleri. İstanbul: Der Yayınları.

Demirel, Ö. (2012). Yabancı dil öğretimi. Ankara: Pegem Akademi.

Derman, S., \& Köksal, O. (2013). Yabancllara Türkçe öğretiminde çoklu zekâ (Multiple intelligences) Uygulamaları. M. Durmuş, \& A. Okur (Ed.), Yabancılara Türkçe Öğretimi El Kitabı (s. 135-142). Ankara: Grafiker Yayınları.

Dilidüzgün, Ş. (2015). Eylem odaklı yaklaşım bağlamında yabancı dil olarak türkçe öğretiminde yazma etkinlikleri. Dil Ĕ̆itimi ve Araşttrmaları Dergisi, 1(2), 16-34.

Durmuş, M. (2013a). Dil öğretiminin erken dönemleri ve dil bilgisi-çeviri yöntemi (Grammartranslation method). M. Durmuş, \& A. Okur (Ed.), Yabancılara Türkçe Öğretimi El Kitabı (s. 4954). Ankara: Grafiker Yayınları.

Durmuş, M. (2013b). Doğrudan yöntem (Direct method) ve Berlitz okullarındaki uygulamalar. M. Durmuş, \& A. Okur (Ed.), Yabancılara Türkçe Öğretimi El Kitabı (s. 55-60). Ankara: Grafiker Yayınları.

Ekawati, A. D. (2017). The effect of TPR and audio-lingual method in teaching vocabulary viewed from students' IQ. Journal of ELT Research, 2(1), 55-67.

Enginarlar, H. (1983). Yabancı dil öğretiminde çeşitli yaklaşımlar ve işlevsel kavramsal yaklaşım. Ortaöğretim Kurumlarında Yabancı Dil Öğretimi ve Sorunları (s. 45-68). içinde Türk Eğitim Derneği Yayınları.

Erdem, M. D., Gün, M., \& Sever, P. (2015). Türkçenin yabancı dil olarak öğretiminde yöntem seçimi ve alternatif yöntemler. Turkish Studies International Periodical for the Languages, Literature and History of Turkish or Turkic, 10(11), 549-566.

Gardner, H. (1999). Intelligence reframed. New York: Basic Books.

Göçer, A. (2017a). Türkçenin yabancı dil olarak öğretiminde iletişimsel yöntemin özellikleri, kullanımı ve işlevleri. International Journal of Languages' Education and Teaching, 5(4), 1-16.

Göçer, A. (2017b). Görev temelli öğrenme yönteminin türkçenin ikinci dil olarak öğretiminde kullanımı, özellikleri ve işlevleri. International Journal of Language Academy, 5(2), 313-328.

Güçlü, B., Arslan, M., \& Üstünyer, İ. (2017). Teaching vocabulary in turkish language for foreigners at beginner level using suggestopedia. International Journal of Research in Social Sciences, 7(11).

Gün, M. (2013a). İletişimsel yöntem (Communicative method). M. Durmuş, \& A. Okur (Ed.), Yabancılara Türkçe Öğretimi El Kitabı (s. 111-114). Ankara: Grafiker Yayınları.

Gün, M. (2013b). Görsel-işitsel yöntem (Audio-visual method). M. Durmuş, \& A. Okur (Ed.), Yabancılara Türkçe Öğretimi El Kitabı (s. 115-117). Ankara: Grafiker Yayınları.

Güneş, F. (2013a). Türkçe öğretimi yaklaşımlar ve modeller. Ankara: Pegem Akademi Yayınları.

Gür, H. (1995). Yabanc1 dil öğretiminde yöntem sorunu. Dil Dergisi, 28, 30-38. 
Gür, H., \& Gür, A. K. (1995). Dil öğretim yöntemleri (3): 1. İşitsel-görsel yöntem, 2. Bilişsel yöntem, 3. Seçmeci yöntem. Dil Degisi(35), 72-79.

Güzel, A., \& Barın, E. (2013). Yabancı dil olarak türkçe öğretimi. Ankara: Akçă̆ Yayınları.

Haley, M. H. (2004). Learner-centered instruction and the theory of multiple intelligences with second language learners. Teachers College Record, 106(1), 163-180.

Hao, Y. (2017). EFL teaching methods. Journal of Language Teaching and Research, 8(4), 742-749.

Işık, A. (2008). Yabancı dil eğitimimizdeki yanlışlar nereden kaynaklanıyor? Journal of Language and Linguistic Studies, 4(2), 15-26.

İşcan, A. (2011). yabancılara türkçe öğretiminde Suggestopedia'nın (Telkin yöntemi) kullanımı. Turkish Studies - International Periodical For The Languages, terature and History of Turkish or Turkic, 6(1), 1317-1322.

İscan, A. (2017). The use of Eclectic Method in teaching turkish to foreign students. Journal of Education and Practice, 8(7), 149-153.

Johnson, D. W., Johnson, R. T., \& Holubec, E. J. (1993). Circles of learning. Edina, MN: Interaction Book Company.

Kırkgöz, Y. (2015). Görev temelli yöntem (Task-based method). N. Bekleyen (Ed.), Dil Öğretimi (s. 231244). Ankara: Pegem Akademi.

Kocaman, A. (1983). Yabancı dil öğretiminde yeni yönelimler. Ortaöğretim Kurumlarında Yabancı Dil Öğretimi ve Sorunları (s. 1-11). içinde Türk Eğitim Derneği Yayınları.

Kurt, M. (2010). Türkçenin yabancılara öğretimi. Düşünce Dünyasında Türkiz, 117-124.

Larsen-Freeman, D. (2011). Tecniques and principles in language teaching. Oxford University Press.

Li, W. (2012). An Eclectic Method of college English teaching. Journal of Language Teaching and Research, 3(1), 166-171.

Liang, X., Mohan, B. H., \& Early, M. (1998). Issues of cooperative learning in ESL classes: A literature review. TESL Canada Journal, 15(2), 13-23.

Liu, Q., \& Shi, J. (2007). An analysis of language teaching approaches and methods - Effectiveness and weakness. US-China Education Review, 4(1), 69-71.

Long, M. H. (2007). Texts, tasks, and the advanced learner. M. H. Long (Ed.), Problems in SLA (s. 119138). Mahwah, NJ: Lawrence Erlbaum.

McKenzie, W. (2002). Multiple intelligences and instructional technology: A manual for every mind. Eugene, OR: International Society for Technology in Education.

Melanlıŏ̆lu, D. (2013a). Kültürler arası iletișim odaklı yaklaşım (Intercultural communication approach). M. Durmuş, \& A. Okur (Ed.), Yabancılara Türkçe Öğretimi El Kitabı (s. 129-134). Ankara: Grafiker Yayınları.

Melanlıŏlu, D. (2013b). Eklektik (Seçmeci) yöntem (Eclectic method). M. Durmuş, \& A. Okur (Ed.), Yabancılara Türkçe Öğretimi El Kitabı (s. 119-120). Ankara: Grafiker Yayınları.

Melanlıŏlu, D. (2013c). Sessiz yol (The silent way). M. Durmuş, \& A. Okur (Ed.), Yabancllara Türkçe Öğretimi El Kitabı (s. 83-86). Ankara: Grafiker Yayınları.

Memiş, M. R., \& Erdem, M. D. (2013). Yabancı dil öğretiminde kullanılan yöntemler, kullanım özellikleri ve eleştiriler. Turkish Studies - International Periodical For The Languages, Literature and History of Turkish or Turkic, 8(9), 297-318.

Nunan, D. (2011). Task-based language teaching. Beijing: Foreign Language teaching and Research Press.

Olsen, R. W.-B., \& Kagan, S. (1992). About cooperative learning. C. Kessler (Ed.), Cooperative language learning: A teacher's resource book (s. 1-30). Englewood Cliffs, NJ: Prentice Hall. 
Paker, T. (2015). İletişimsel dil öğretim yöntemi (Communicative language teaching method). N. Bekleyen (Ed.), Dil Öğretimi (s. 187-210). Ankara: Pegem Akademi.

Richards, J. C., \& Rodgers, T. S. (2002). Approaches and methods in language teaching. Cambridge University Press.

Samuda, V., \& Bygate, M. (2008). Tasks in second language learning. New York: Palgrave Macmillan.

Sebüktekin, H. (1973). Yabancı dil öğretiminde yöntem. Boğaziçi Üniversitesi Dergisi, Humaniter Bilimler-Humanities, 1, 95-100.

Shuang, L., \& Xin, M. (2011). A comparative study of the features of the direct method and the communicative approach. International Conference on Computational and Information Sciences, 1068-1071.

Slavin, R. E. (1995). Cooperative learning: Theory, research, and practice. Boston: Allyn \& Bacon.

Şenel, M. (2015). Dilbilgisi çeviri yöntemi (Grammar-translation method). N. Bekleyen (Ed.), Dil Öğretimi (s. 23-39). Ankara: Pegem Akademi.

Tosun, C. (2006). Yabancı dil öğretim ve öğreniminde eski ve yeni yöntemlere yeni bir bakış. Çukurova Üniversitesi Fen-Edebiyat Fakültesi, Journal of Arts and Sciences 5, 79-88.

Uysal, B. (2019). Yabancı dil öğretimi yaklaşımları. Ü. Şen (Ed.), Yabancı Dil Olarak Türkçe Öğretimi (24-40). Ankara: Pegem Akademi.

Uzuntaş, A. ve Yıldız, C. (2017). Dil öğretiminde yaklaşımlar, yöntemler, strateji ve teknikler. H. Develi, C. Yıldız, M. Balcı, İ. Gültekin ve D. Melanlığlu (Ed.), Uygulamalı Türkçenin Yabancı Dil Olarak Öğretimi El Kitabr (205-240). İstanbul: Kesit Yayınları.

Widodo, H. P. (2005). Teaching children using a total physical response (TPR) method: Rethinking. Bahasa Dan Seni, 33(2), 235-248.

Willis, D., \& Willis, J. (2012). Doing task-based teaching. Oxford, UK: Oxford University Press.

Yaprak, Z. (2015). İçerik temelli öğretim / İçerik ve dil bütünleştirmeli öğrenme. N. Bekleyen (Ed.), Dil Öğretimi (s. 211-229). Ankara: Pegem Akademi.

Yaylı, D., \& Yaylı, D. (2011). Yabancı dil öğretimi yaklaşımları ve yöntemleri. D. Yaylı, \& Y. Bayyurt (Ed.), Yabancılara Türkçe Öğretimi Politika Yöntem ve Beceriler (s. 7-28). Ankara: Anı Yayıncılık.

Yılmaz, F., \& Kocaoğlu, İ. (2017). Yabancılara Türkçe öğretiminde görev temelli yaklaşımı kullanmaya yönelik etkinlikler. International Journal of Languages' Education and Teaching, 5(3), 234-248.

Yorulmaz, M. (2009). Göreve dayal öğretim yönteminin türkçenin yabancı dil olarak öğretiminde dinleme becerisinde kullanılmasının avantajları. Yayınlanmamış yüksek lisans tezi, Trakya Üniversitesi, Sosyal Bilimler Enstitüsü, Edirne.

Young, R. (2000). The silent way. M. Byram (Ed.), Routledge Encyclopedia of Language Teaching and Learning (s. 546-548). London: Routledge. 